\title{
Cadmium toxicity in African yam bean (Sphenostylis stenocarpa) (Hochst. ex A.Rich.) Harms genotypes
}

\author{
Pascal C. OKOYE ${ }^{1}, 2$, Geoffrey O. ANOLIEFO ${ }^{1}$, Beckley IKHAJIAGBE ${ }^{1}$, Edokpolor O. OHANMU ${ }^{1,3}$, \\ Francis A. IGIEBOR ${ }^{1,4}$, and Ephraim ALIU ${ }^{1,5}$
}

Received May 22, 2018; accepted October 24, 2019.

Delo je prispelo 22. maja 2018, sprejeto 24. oktobra 2019.

\begin{abstract}
Cadmium toxicity in African yam bean (Sphenostylis stenocarpa) (Hochst. ex A.Rich.) Harms genotypes

Abstract: The aim of the study was to investigate the growth responses of African yam bean (Sphenostylis sternocarpa (Hochst. ex A. Rich.) Harms (AYB) to cadmium pollution. Top garden soil $(0-10 \mathrm{~cm})$ was obtained as pooled and polluted with cadmium (as $\mathrm{CdCl}_{2}$ ) at the rate of $12 \mathrm{mg} \mathrm{kg}^{-1}$, which is equivalent to 3 times the ecotoxicological screening value of $\mathrm{Cd}$. The polluted soils were made ready for use 3 days later. Nine selected AYB accessions (TSs-87, TSs-89, TSs-90, TSs-91, TSs-92, TSs-93, TSs-94, TSs-95, and TSs-96) were pre-soaked for 30 minutes and then sown in the polluted and unpolluted soils. Data collected were subjected to ANOVA, and means were separated at $95 \%$ confidence interval. Results showed that incidence of cadmium pollution significantly delayed seedling emergence in all tested AYB accessions by at least one day $(p<0.05)$. Despite exposure to Cd, TSs-96 attained $50 \%$ emergence faster than other accessions. Although there were general reductions in yield due to exposure to Cd, TSs-92 showed the least percentage yield reduction (50\%), compared to $74 \%$ yield reduction in TSs93, thereby suggesting a comparatively better yield capacity compared to the other test accessions. Overall, decrease in total chlorophyll content seems to be the major reason of injury in Cd-exposed plants.
\end{abstract}

Key words: toxicity; heavy metal; Sphenostylis stenocar$p a$; cadmium; yield
Toksičnost kadmija za izbrane genotipe afriškega gomoljastega fižola(Sphenostylis stenocarpa) (Hochst. ex A.Rich.) Harms

Izvleček: Namen raziskave je bil preučiti rastni odziv afriškega gomoljastega fižola (Sphenostylis sternocarpa (Hochst. ex A. Rich.) Harms (AYB) na onesnaženje tal s kadmijem. Vzorčena je bila vrhnja plast vrtnih tal $(0-10 \mathrm{~cm})$, onesnažena s kadmijem ( $k$ ot $\mathrm{CdCl}_{2}$ ) v velikosti $12 \mathrm{mg} \mathrm{kg}^{-1}$, kar je trikratni ekvivalent priporočene ekotoksikološke vrednosti za Cd. Onesnažena tla so bila pripravljena za poskus v treh dneh. Izbranih je bilo devet akcesij AYB (TSs-87, TSs-89, TSs90, TSs-91, TSs-92, TSs-93, TSs-94, TSs-95, in TSs-96), katerih semena so bila predhodno namočena za 30 minut in potem posejana $\mathrm{v}$ onesnažena in neonesnaženea tla. Zbrani podatki so bili ovrednoteni z ANOVA, kjer so bila poprečja ločena pri $95 \%$ intervalu zaupanja. Rezultati so pokazali, da je onesnaženje s kadmijem značilno zamaknilo vznik kalic AYB pri vseh preiskušenih akcesijah najmanj za en dan $(p<0,05)$. Kljub izpostavitvi Cd, je akcesija TSs-96 dosegla $50 \%$ kalivost hitreje kot vse ostale. Kljub splošnemu upadu pridelka zaradi izpostavljenosti kadmiju, je akcesija TSs-92 pokazala najmanjši upad pridelka (50\%), v primerjavi s $74 \%$ upadom pri akcesiji TSs-93, kar kaže na njeno boljšo primerjalno sposobnost prilagoditve $v$ primerjavi z drugimi genotipi. Na splošno je bil glavni razlog poškodb zaradi Cd pri vseh izpostavljenih rastlinah upad celokupne vsebnosti klorofila.

Ključne besede: toksičnost; težka kovina; Sphenostylis sternocarpa; kadmij; pridelek.

\footnotetext{
1 University of Benin, Environmental Biotechnology and Sustainability Research Group, Department of Plant Biology and Biotechnology, Nigeria

2 Corresponding author, e-mail: pascal.okoye@lifesci.uniben.edu

3 Edo University, Department of Plant Biology and Biotechnology, Iyamho, Nigeria

4 Wellspring University, Department of Microbiology, College of Natural and Applied Sciences, Benin City, Nigeria

5 Iowa State University,Department of Genetics, Development, and Cell Biology, College of Agriculture and Life Sciences, United States of America
} 


\section{INTRODUCTION}

Anthropogenic activities, including increased rate of industrialization, concentrated agriculture, and allembracing mining accompanied by escalating population and rapid civilization, have not only inflicted damaging effect on the accessibility of natural endowments but also resulted in extensive and severe contamination of fundamental constituents of life worldwide (Abolghassem et al., 2015). Amidst the repercussion of human-induced disturbance of natural biogeochemical cycles, accentuated buildup of heavy metals (HMs) is of great concern due to dietetic, biological, and environmental reasons (Ali et al., 2013). Aside from having atomic mass of over 20 and density higher than $5 \mathrm{~g} \mathrm{~cm}^{-3}$, HMs can trigger mutagenic, cytotoxic and genotoxic repercussions on plants, animals, and higher beings via the food chains, irrigation, aquifers, and surrounding atmosphere (Rascio \& Navari-Izzo, 2011). Even so, they are not biodegradable and are extremely persistent in water and soil.

Cadmium $(\mathrm{Cd})$, a powerful phytotoxic heavy met$\mathrm{al}$, is frequently released into the arable soil from industrial processes and farming practices (Sarvajeet et al., 2013). It is estimated that around 30,000 tons of $\mathrm{Cd}$ are released into the environment annually, of which 13,000 tons resulted from human activity. Cd is easily taken up by plant roots and transported to aerial parts, thus entering into the food chain causing health problems in animals and humans (Gallego et al., 2012) . Pál et al. (2006) recounted that the uptake of Cd ions takes place in competition with that of essential elements such as $\mathrm{K}, \mathrm{Mg}, \mathrm{Ca}$, and $\mathrm{Fe}$, across the same transmembrane transporter. The main symptoms of Cd-induced toxicity in plants are stunted growth, chlorosis, leaf epinasty, altered chloroplast ultrastructure, photosynthetic inhibition, inactivation of enzymes in $\mathrm{CO}_{2}$ fixation, induced lipid peroxidation, suppression of pollen germination and tube growth, and disturbance of the nitrogen $(\mathrm{N})$ and sulphur (S) metabolism (Gill \& Tuteja, 2011). The disproportionate uptake of the element from the soil creates two fold problems; first is the contamination of harvested crops, which become the entry route of heavy metal in human diet, and secondly the inhibition of metabolic processes and, in severe cases, death of plants results in heavy decline in crop yield as well as potential threat to food security (Singh \& Aggarwal, 2006). Zong et al. (2007) have reported that plant species and also genotypes within the species differ greatly in their tolerance to Cd stress.

African yam bean (AYB), though an underutilized legume, contains a large amount of essential amino acids, including lysine, histidine, methionine, and iso- leucine, that are vital to human metabolism. Food and Agriculture Organisation, and Wealth Health Organization have described the amino acid profile of AYB as being comparable with those of whole hen's eggs, and therefore meet the daily requirement of the organizations (Adewale \& Dumet, 2010). Potter (1992) opined that AYB has the potential of fostering food security in Africa due to its resistance to pest infestation. While lack of improved varieties with dwarf erect architecture, shorter growth period and easier to cook seed coats have been identified as obstacles to large scale commercial cultivation of S. stenocarpa stenocarpa (Носнsт. ex A.Rich.) Harms, effects of elevated environmental pollution with heavy metals pose a great threat to the potential use of the crop as source of plant protein in developing nations.

Heavy metals are known to hamper enzyme functions needed for plant metabolism through their interference with microbial activities in the soil. These deleterious effects (direct and indirect) culminate in dwindling plant growth which at times leads to domino effects of plant's death. There is need to identify possible cultivars that are resistant to toxic effects of HMs; hence the present study suffices. Cadmium (Cd) was selected for this study on the basis of its preponderance in the environment due to its presence in sewage and certain fertilizers used in agriculture (Gallego et al., 2012). Therefore, this investigation was undertaken to evaluate the growth and physiological responses of African yam bean (AYB) genotypes to cadmium pollution, as well as draw conclusion from results obtained on the ability of AYB to thrive on cadmium polluted soils without posing health risks to both animal and human consumers upon maturity. Furthermore, the question the present study intended to answer was whether cadmium pollution could elicit morphological and physiological changes in selected accessions of AYB and, if possible, which part of the plant could be adjudged the main indicator of cadmium-pollution related stress.

\section{MATERIALS AND METHODS}

\subsection{COLLECTION AND POLLUTION OF SOIL}

Top soil $(0-10 \mathrm{~cm})$ was obtained as pooled from 10 locations devoid of previous exogenous activities with heavy metals or fertilizers. Before proceeding with the experiment, a sample of the pooled soil was analyzed according to Asema et al. (2015) for selected physicochemical parameters. Twenty (20) $\mathrm{kg}$ of the sun-dried soil was thereafter measured into experimental bags. 


\subsection{PROCUREMENT OF METAL AND SOIL CON- TAMINATION}

The chloride form of $\mathrm{Cd}$, chosen on the basis of its high solubility in water as well as availability within the locality of the present study, was used in the experiment $\left(\mathrm{CdCl}_{2}\right)$. The water holding capacity $(1.6 \mathrm{l})$ of the soil was predetermined (Anoliefo et al., 2016) to be $816 \mathrm{ml} \mathrm{kg}^{-1}$. Thus, $0.24 \mathrm{~g}$ ( $3 \mathrm{ESV}$ of Cd) of cadmium chloride $\left(\mathrm{CdCl}_{2}\right)$ was dissolved in $1.6 \mathrm{l}$ of water and used to saturate $20 \mathrm{~kg}$ of soil and allowed to attenuate naturally for a period of one week. The ecological screening value (ESV) of Cd is $4 \mathrm{mg} \mathrm{kg}^{-1}$ (Efroymson et al, 1997a) which is the limit above which Cd becomes detrimental to plants. A second set of experimental bags were presented, but these were not polluted with Cd. AYB accessions were sown in Cd-polluted and clean soils respectively, with a view to ascertaining response to Cdinduced stress.

\subsection{PLANTING OF AYB SEEDS}

Viable accessions of AYB (TSs-87, TSs-89, TSs-90, TSs-91, TSs-92, TSs-93, TSs-94, TSs-95, and TSs-96) were obtained from the Genetic Resource Centre (GRC) of the International Institute of Tropical Agriculture (IITA), Ibadan, Nigeria. Five seeds (unsterilized) were sown in each experimental bag after soaking in distilled water for about 30 minutes. After two weeks of sowing of AYB, the plants were staked on $3 \mathrm{~m}$-long poles.

\subsection{MORPHOLOGICAL STRESS RESPONSES}

The physical appearances of the plant in response to the experimental conditions were observed and recorded on periodic basis. Care was also taken to ensure that the progression of chlorosis was recorded. In this case, whenever chlorosis was noted, the leaf was immediately tagged so that chlorotic progress would be followed up till when the leaf became entirely chlorotic. Similar procedure was followed in order to designate the progression of necrosis in Cd-exposed and unexposed plants.

\subsection{ASSESSMENT OF PLANT PRODUCTIVITY AND GROWTH INDICES}

The assessment of plant productivity adopted in this study was based on the previous works of El-shesheny et al. (2014) while the growth indices employed in monitoring the development of the test plant was according to the previous research findings of Ozalkan et al. (2010). Plant growth indices including leaf area index (LAI), relative growth rate (RGR), net assimilation rate (NAR), and crop growth rate (CGR) were determined according to Ozalkan et al. (2010). Other plant parameters considered were plant dry mass (Bashan \& de-Bashan, 2005), catalase activity (Aebi, 1983), superoxide dismutase activity (Kumar et al., 2012) and total nitrogen (Raveh \& Avnimelech, 1979).

\subsection{STATISTICAL ANALYSIS}

Data were collected and subjected to analysis of variance and differences in means were separated at $95 \%$ confidence interval using SPSS ${ }^{\circ}$ software version 20.

\section{RESULTS AND DISCUSSION}

The physicochemical composition of the soil used for the experiment has been presented on Table 1 . Results showed that the $\mathrm{pH}$ level of the soil was 5.97 prior to contamination with cadmium (Cd); while electric conductivity and total nitrogen content were $301.21 \mathrm{~S} \mathrm{~cm}^{-1}$ and $0.18 \%$ respectively. There was presence of heavy metals in the garden soil; concentration of iron (Fe) was $1011.92 \mathrm{mg} \mathrm{kg}^{-1}$ whereas zinc $(\mathrm{Zn})$ and manganese $(\mathrm{Mn})$ were $30.12 \mathrm{mg} \mathrm{kg}^{-1}$ and $17.03 \mathrm{mg} \mathrm{kg}^{-1}$ correspondingly. $\mathrm{Cd}$ concentration in the experimental site was negligible at a concentration less than $0.001 \mathrm{mg}$ $\mathrm{kg}^{-1}$ The description of AYB collected from IITA seed bank showed that the accessions originated in Nigeria.

\subsection{EFFECT OF CADMIUM ON MORPHOLOGI- CAL PARAMETERS OF YOUNG EMERGENT OF AYB}

It generally took between 2 - 3 days for emergence of AYB in unexposed and Cd-exposed conditions. In the present study, a plant was tagged "Cd-exposed" when exposed to $\mathrm{Cd}$, the plants that were not subjected to Cd contamination were tagged "Cd-unexposed". Emergence was noticed in Cd-unexposed TSs-87 and TSs- 89 at 2 days of sowing, but delayed by 1 day in their Cd-exposed counterparts $(p<0.05)$.Observably, it took an average difference of 1 day between the Cdexposed and unexposed AYB accessions for half of the seeds to emerge irrespective of prior exposure to cadmium pollution. However, while the final emergence 
was $100 \%$ in all unexposed accessions of AYB, there was an average of $25 \%$ reduction in final emergence of seeds exposed to cadmium contamination. Presence of metal did not in any way affect the first day of emergence of the test plant. Perhaps, this may be because water, that was readily available in both treated and untreated plants, is a major requirement for germination initiation (Raveneau et al., 2011). Nevertheless, beyond the first day of germination, the effects of cadmium became evident, for example the time taken to reach $50 \%$ emergence was usually delayed by one day in the Cd-exposed plants. Thus, the presence of the metal warranted that for the time to $50 \%$ emergence to be attained, it usually would delay by one day in Cdexposed plants compared to the unexposed counterparts. Dobroviczká et al. (2013) reported that bean seed grown in Cd polluted soil did not show any apparent effect on the initial emergence parameters of the test plant. However, Thakur \& Singh (2014) observed that with regard to progression of seedling emergence of soybean there was a slight decrease in the germination and emergence percentage of the Cd-exposed plants. These findings support the argument of the present study, in relation to the effects of $\mathrm{Cd}$ contamination on seedling emergence, that although emergence of seedlings was not inhibited during germination, there was a decrease by one day in the time to $50 \%$ emergence in Cd-exposed plants.

In assessing plant dry mass, it was observed that there was a general reduction in plant dry mass when seeds were exposed to cadmium pollution. Dry mass of unexposed TSs- 89 decreased from $0.18 \mathrm{~g}$ to $0.14 \mathrm{~g}$ after exposure to cadmium, whereas those of TSs-90 and TSs-92 showed similar outcome $(0.18-0.15 \mathrm{~g})$ and $(0.17-0.14 \mathrm{~g})$ respectively. Interestingly, the average reduction in plant dry mass occasioned by cadmium pollution in all tested AYB accessions was $0.035 \mathrm{~g}$ (19.44\%). This could be due to Cd interference with

Table 1: Physicochemical properties of soil and African yam bean seed description. These are background mean concentrations $(\mathrm{n}=5)$.

\begin{tabular}{|c|c|c|c|c|c|c|}
\hline \multicolumn{3}{|l|}{ Physicochemical properties of soil } & \multicolumn{4}{|c|}{ Description of African yam bean collected from IITA } \\
\hline Parameters & $\begin{array}{l}\text { Mean value } \\
(\mathrm{n}=5)\end{array}$ & $\begin{array}{l}\text { Accession } \\
\text { name }\end{array}$ & $\begin{array}{l}\text { Country of } \\
\text { origin }\end{array}$ & GRIN taxa & $\begin{array}{l}\text { Taxonomy } \\
\text { number }\end{array}$ & $\begin{array}{l}\text { Collecting } \\
\text { number }\end{array}$ \\
\hline $\mathrm{Ph}$ & $5.97 \pm 0.67$ & TSs-87 & Nigeria & GRIN:35250 & 3602 & TB78-182-B \\
\hline Electric conductivity $\left(\mu \mathrm{sm}^{-1}\right)$ & $301.21 \pm 23.01$ & TSs-89 & Nigeria & GRIN:35250 & 3602 & TB78-187 \\
\hline Total organic carbon (\%) & $0.49 \pm 0.09$ & TSs-90 & Nigeria & GRIN:35250 & 3602 & TB78-187-B \\
\hline Total nitrogen $(\%)$ & $0.18 \pm 0.06$ & TSs-91 & Nigeria & GRIN:35250 & 3602 & TB78-187-C \\
\hline \multicolumn{2}{|c|}{ Exchangeable acidity (meq $\left.100 \mathrm{~g}^{-1}\right) 0.22 \pm 0.08$} & TSs-92 & Nigeria & GRIN:35250 & 3602 & TB78-187-D \\
\hline $\mathrm{Na}\left(\right.$ meq $\left.100 \mathrm{~g}^{-1}\right)$ & $10.90 \pm 2.11$ & TSs-93 & Nigeria & GRIN:35250 & 3602 & TB78-187-E \\
\hline $\mathrm{K}\left(\mathrm{meq} 100 \mathrm{~g}^{-1}\right)$ & $1.48 \pm 0.62$ & TSs-94 & Nigeria & GRIN:35250 & 3602 & TB78-190 \\
\hline $\mathrm{Ca}\left(\mathrm{meq} 100 \mathrm{~g}^{-1}\right)$ & $14.32 \pm 3.10$ & TSs-95 & Nigeria & GRIN:35250 & 3602 & TB78-190-B \\
\hline $\mathrm{Mg}\left(\right.$ meq $\left.100 \mathrm{~g}^{-1}\right)$ & $12.01 \pm 3.22$ & TSs-96 & Nigeria & GRIN:35250 & 3602 & TB78-190-C \\
\hline $\mathrm{NO}^{-2}\left(\mathrm{mg} \mathrm{kg}^{-1}\right)$ & $16.43 \pm 2.03$ & TSs-87 & Nigeria & GRIN:35250 & 3602 & TB78-182-B \\
\hline $\mathrm{NO}^{-3}\left(\mathrm{mg} \mathrm{kg}^{-1}\right)$ & $30.01 \pm 4.28$ & TSs-89 & Nigeria & GRIN:35250 & 3602 & TB78-187 \\
\hline Soil texture & & TSs-90 & Nigeria & GRIN:35250 & 3602 & TB78-187-B \\
\hline Clay (\%) & $5.43 \pm 0.88$ & - & - & - & - & - \\
\hline Silt $(\%)$ & $7.36 \pm 1.74$ & - & - & - & - & - \\
\hline Sand (\%) & $84.81 \pm 12.12$ & - & - & - & - & - \\
\hline Heavy metals & & - & - & - & - & - \\
\hline $\mathrm{Fe}\left(\mathrm{mg} \mathrm{kg}^{-1}\right)$ & $1011.92 \pm 73.38$ & - & - & - & - & - \\
\hline $\mathrm{Cd}\left(\mathrm{mg} \mathrm{kg}^{-1}\right)$ & $<0.001$ & - & - & - & - & - \\
\hline $\mathrm{Mn}\left(\mathrm{mg} \mathrm{kg}^{-1}\right)$ & $17.03 \pm 3.22$ & - & - & - & - & - \\
\hline $\mathrm{Pb}\left(\mathrm{mg} \mathrm{kg}^{-1}\right)$ & $0.03 \pm 0.01$ & - & - & - & - & - \\
\hline $\mathrm{Cu}\left(\mathrm{mg} \mathrm{kg}^{-1}\right)$ & $3.93 \pm 0.01$ & - & - & - & - & - \\
\hline $\mathrm{Zn}\left(\mathrm{mg} \mathrm{kg}{ }^{-1}\right)$ & $30.12 \pm 3.06$ & - & - & - & - & - \\
\hline
\end{tabular}


physiological processes such as photosynthesis, translocation and partitioning of dry material in AYB. As has been shown (Neto \& Bartels, 1992), water stress in cowpea decreased photosynthetic rate which in turn reduced yield, and ultimately plant dry matter, by decreasing the amount of assimilates required for plant growth and yield. An important observation made during the present study was the fact that average reduction in plant dry mass occasioned by cadmium pollution in all tested AYB accessions was $19.44 \%$. This remark agrees with the findings of Hassanein et al. (2013) who subjected lettuce and turnip to heavy metal stress and then obtained $19.45 \% \mathrm{Cd}$-mediated reduction in shoot dry mass for turnip. Naz et al. (2015) reported similar observation for chickpea after exposure to heavy metal stress. Incidence of cadmium contamination resulted in shrinking in size of stem diameter in AYB accessions. Stem diameter ranged from $3 \mathrm{~cm}$ to $4.03 \mathrm{~cm}$ in unexposed and $2.26 \mathrm{~cm}$ to 3.89 in Cd-exposed plants. Aside from TSs-95 where the different in stem diameter between Cd-exposed and unexposed plants is $1 \mathrm{~cm}$, other AYB accessions showed a difference less than $1 \mathrm{~cm}$ with slight variation. Interestingly, cadmium contamination had no effect on stem diameter of TSs-93 as reading remained $3.03 \mathrm{~cm}$ in both Cd-exposed and unexposed plants. Bhattarai \& Subudhi (2018) revealed that varieties of plant within the same species show unique tolerance to environmental stress based on their genome. However, the scope of the present study could not pinpoint the gene that conferred the unique characteristic to TSs-93.

Results for seedling vigour of African yam bean after exposure to cadmium indicated that heavy metal contamination had notable effect on test plants (Table 2). At 28 days after sowing, estimated seedling vigour index I for unexposed TSs-87 was 47.91 as against 41.03 recorded in the $\mathrm{Cd}$-exposed accession. Incidence of cadmium pollution resulted in reduction of vigour index I from 68.47 in unexposed TSs- 89 to 46.38 in the Cd-exposed counterpart. Although similar observation was recorded for TSs-92 in which seedling vigour index I decreased from 45.02 (unexposed) to 40.01 (Cdexposed), effects of cadmium pollution was not significant with respect to seedling vigour index I of TSs-92

Table 2: Effect of treatment on germination parameters of African yam bean at 7 days after sowing

\begin{tabular}{|c|c|c|c|c|c|c|c|c|c|}
\hline Treatment & $\begin{array}{l}\text { Final emer- } \\
\text { gence } \%\end{array}$ & $\begin{array}{l}50 \% \text { emer- } \\
\text { gence (days) }\end{array}$ & $\begin{array}{l}\text { Fresh mass } \\
\text { of emergent } \\
(\mathrm{g})\end{array}$ & $\begin{array}{l}\text { Dry } \\
\text { mass of } \\
\text { emergent } \\
\text { (g) }\end{array}$ & $\begin{array}{l}\text { Hypocotyl } \\
\text { length }(\mathrm{cm})\end{array}$ & $\begin{array}{l}\text { Petiole } \\
\text { length } \\
(\mathrm{cm}) 14 \\
\text { days }\end{array}$ & $\begin{array}{l}\text { Stem diam- } \\
\text { eter }(\mathrm{cm})\end{array}$ & $\begin{array}{l}\text { Seedling } \\
\text { vigour } \\
\text { index I }\end{array}$ & $\begin{array}{l}\text { Seedling } \\
\text { vigour } \\
\text { index II }\end{array}$ \\
\hline TSs-87_U & $100.00^{d}$ & $3.10^{\mathrm{a}}$ & $0.41^{\mathrm{i}}$ & $0.15^{\mathrm{efg}}$ & $3.23^{\mathrm{cdef}}$ & $1.03^{\mathrm{ab}}$ & $3.00^{\mathrm{abc}}$ & $47.91^{\mathrm{i}}$ & $0.23^{\mathrm{e}}$ \\
\hline TSs-87_Cd & $62.50^{\mathrm{a}}$ & $4.03^{c}$ & $0.34^{\mathrm{fg}}$ & $0.13^{\mathrm{d}}$ & $2.60^{a b c}$ & $0.93^{\mathrm{ab}}$ & $2.26^{\mathrm{a}}$ & $41.03^{f}$ & $0.13^{\mathrm{cd}}$ \\
\hline TSs-89_U & $75.00^{b}$ & $3.10^{\mathrm{a}}$ & $0.41^{\mathrm{i}}$ & $0.18^{\mathrm{ij}}$ & $2.90^{\text {bcde }}$ & $1.36^{\mathrm{b}}$ & $4.00^{\mathrm{d}}$ & $68.47^{1}$ & $0.23^{\mathrm{e}}$ \\
\hline TSs-89_Cd & $62.66^{\mathrm{a}}$ & $4.03^{c}$ & $0.35^{\mathrm{g}}$ & $0.14^{\text {ef }}$ & $2.13^{a}$ & $1.30^{\mathrm{ab}}$ & $3.25^{b c}$ & $46.38^{\mathrm{h}}$ & $0.11^{\mathrm{bcd}}$ \\
\hline TSs-90_U & $100.00^{\mathrm{d}}$ & $3.16^{\mathrm{a}}$ & $0.41^{\mathrm{i}}$ & $0.18^{i j}$ & $3.58^{\mathrm{e}}$ & $1.40^{\mathrm{b}}$ & $3.06^{\mathrm{abc}}$ & $82.01^{\mathrm{m}}$ & $0.15^{\mathrm{d}}$ \\
\hline TSs-90_Cd & $87.50^{c}$ & $3.46^{\mathrm{b}}$ & $0.37^{\mathrm{h}}$ & $0.15^{\text {efgh }}$ & $2.11^{\mathrm{a}}$ & $1.03^{\mathrm{ab}}$ & $2.26^{\mathrm{a}}$ & $22.85^{c}$ & $0.08^{\mathrm{b}}$ \\
\hline TSs-91_U & $100.00^{\mathrm{d}}$ & $3.10^{\mathrm{a}}$ & $0.32^{\mathrm{d}}$ & $0.11^{b c}$ & $2.94^{\text {bcde }}$ & $0.93^{\mathrm{ab}}$ & $3.79^{\mathrm{d}}$ & $33.57^{\mathrm{d}}$ & $0.26^{\mathrm{e}}$ \\
\hline TSs-91_Cd & $62.50^{\mathrm{a}}$ & $4.03^{c}$ & $0.26^{c}$ & $0.14^{\mathrm{ef}}$ & $2.10^{\mathrm{a}}$ & $0.86^{\mathrm{ab}}$ & $2.88^{\mathrm{ab}}$ & $16.61^{a}$ & $0.12^{\mathrm{cd}}$ \\
\hline TSs-92_U & $100.00^{\mathrm{d}}$ & $3.03^{a}$ & $0.40^{\mathrm{i}}$ & $0.17^{\mathrm{ij}}$ & $2.58^{\mathrm{abc}}$ & $1.06^{\mathrm{ab}}$ & $4.01^{\mathrm{d}}$ & $45.02^{g}$ & $0.23^{\mathrm{e}}$ \\
\hline TSs-92_Cd & $66.67^{a b}$ & $4.06^{c}$ & $0.33^{\mathrm{de}}$ & $0.14^{\mathrm{e}}$ & $2.1^{\mathrm{a}}$ & $1.01^{\mathrm{ab}}$ & $3.89^{\mathrm{d}}$ & $40.00^{\mathrm{f}}$ & $0.11^{\mathrm{bcd}}$ \\
\hline TSs-93_U & $100.00^{d}$ & $3.06^{\mathrm{a}}$ & $0.52^{\mathrm{k}}$ & $0.18^{j}$ & $3.23^{\text {cdef }}$ & $1.20^{\mathrm{ab}}$ & $3.03^{a b c}$ & $65.75^{\mathrm{k}}$ & $0.33^{f}$ \\
\hline TSs-93_Cd & $62.50^{\mathrm{a}}$ & $4.03^{c}$ & $0.41^{\mathrm{i}}$ & $0.16^{\mathrm{gh}}$ & $2.42^{\mathrm{ab}}$ & $1.36^{\mathrm{b}}$ & $3.03 \mathrm{abc}$ & $55.03^{j}$ & $0.13^{\mathrm{cd}}$ \\
\hline TSs-94_U & $100.00^{\mathrm{d}}$ & $3.03^{a}$ & $0.17^{b}$ & $0.17^{\mathrm{hi}}$ & $2.59^{a b c}$ & $0.93^{\mathrm{ab}}$ & $3.06^{\mathrm{abc}}$ & $86.00^{n}$ & $0.10^{b c}$ \\
\hline TSs-94_Cd & $62.50^{\mathrm{a}}$ & $4.03^{c}$ & $0.13^{\mathrm{a}}$ & $0.03^{\mathrm{a}}$ & $2.81^{\mathrm{abcd}}$ & $1.06^{\mathrm{ab}}$ & $2.85^{\mathrm{ab}}$ & $21.17^{\mathrm{b}}$ & $0.02^{\mathrm{a}}$ \\
\hline TSs-95_U & $100.00^{\mathrm{d}}$ & $5.06^{\mathrm{d}}$ & $0.33^{\mathrm{ef}}$ & $0.16^{\mathrm{fgh}}$ & $0.064^{\mathrm{f}}$ & $1.13^{\mathrm{ab}}$ & $4.03^{\mathrm{d}}$ & $99.30^{p}$ & $0.24^{\mathrm{e}}$ \\
\hline TSs-95_Cd & $62.50^{\mathrm{a}}$ & $6.06^{e}$ & $0.26^{c}$ & $0.11^{\mathrm{ac}}$ & $3.35^{\text {def }}$ & $1.03^{\mathrm{ab}}$ & $3.03 \mathrm{abc}$ & $37.13^{e}$ & $0.14^{\mathrm{d}}$ \\
\hline TSs-96_U & $100.00^{\mathrm{d}}$ & $3.13^{\mathrm{a}}$ & $0.43^{j}$ & $0.16^{\text {fgh }}$ & $2.60^{\mathrm{abc}}$ & $0.93^{\mathrm{ab}}$ & $3.96^{\mathrm{d}}$ & $96.28^{\circ}$ & $0.26^{\mathrm{e}}$ \\
\hline TSs-96_Cd & $75.00^{\mathrm{b}}$ & $5.30^{\mathrm{d}}$ & $0.44^{j}$ & $0.10^{\mathrm{b}}$ & $2.13^{\mathrm{a}}$ & $0.63^{\mathrm{a}}$ & $3.55^{\mathrm{cd}}$ & $33.54^{\mathrm{d}}$ & $0.12^{\text {bcd }}$ \\
\hline$\underline{p-v a l u e}$ & $1.93 \times 10^{-17}$ & $2.52 \times 10^{-24}$ & $7.74 \times 10^{-38}$ & $2.22 \times 10^{-22}$ & $5.52 \times 10^{-6}$ & $4.9 \times 10^{-1}$ & $3.04 \times 10^{-8}$ & $44.34 \times 10^{-55}$ & $1.18 \times 10^{-19}$ \\
\hline
\end{tabular}

Means with the same alphabetic superscripts on the same column do not differ from each other $(p>0.05)$ 
AYB accession. Similarly, unexposed TSs-91 and TSs96 had identical seedling vigour index at 0.26 ; however unlike the situation in TSs-87 and 89, the former had similar response to cadmium pollution with respect to seedling vigour index II at 0.12. Comparable outcomes have been reported in previous investigations (Talebi et al., 2014)

There was general reduction in shoot length of $\mathrm{AYB}$ at 20 weeks after sowing (WAS) as occasioned by cadmium pollution. Shoot length ranged from $104.11 \mathrm{~cm}$ in unexposed TSs-89 plants to $126.18 \mathrm{~cm}$ in the unexposed TSs-93 plant (Table 3). Cadmium pollution triggered the reduction of shoot length in TSs-87 from $112.03 \mathrm{~cm}$ to $93.70 \mathrm{~cm}$ in unexposed and Cd-exposed plants respectively. While TSs-90 showed the lowest shoot length at $84.07 \mathrm{~cm}$ for Cd-exposed accession, Cd-exposed TSs-92 had the longest shoot $(98.71 \mathrm{~cm})$. Similar outcome was observed by Pappalardo et al. (2016) who reported that high concentrations of arsenic, even in combination with $\mathrm{Cd}$, stopped the seminal root emergence from the germinated seed, thus hampering the development of shoot. However, the present investigation observed that reduction in shoot length elicited by cadmium contamination was obvious in older plants than in younger ones. A notable remark from the results was the fact that cadmium pollution had significant effect on the number of leaves per plant in all tested AYB accessions. At 20 WAS, number of leaves in unexposed TSs-87 stood at 38.30 as against 29.07 in Cd-exposed TSs-87. There were over $50 \%$ reduction in number of leaves in TSs-90 (42.13 to 15.26), TSs-91 (40.23 to 18.16 ), TSs-94 (33.39 to 15.10), and TSs-96 (34.40 to 15.01$)$. Generally, reduction in num- ber of leaves impacts on the photosynthetic rate and resultant productivity of plants exposed to cadmium pollution (Eshighi, 2010).

Effect of treatment on below ground parameters of African yam bean at 20 WAS has been presented on Table 3. Results underpinned a general decline in root length in all accessions of AYB due to exposure to cadmium contamination. Unexposed TSs- 87 showed root length of $26.06 \mathrm{~cm}$ while the same that was subjected to cadmium stress had a reduction in root length at $20.10 \mathrm{~cm}$. Similar outcome was observed in unexposed TSs-89 $(21.21 \mathrm{~cm})$, Ts-90 $(26.23 \mathrm{~cm})$, and TSs-91 $(27.06 \mathrm{~cm})$ where root length decreased to $12.30 \mathrm{~cm}, 20.13 \mathrm{~cm}$, and $23.03 \mathrm{~cm}$ in Cd-exposed plant respectively. Observably, there was $50 \%$ reduction in root length of TSs-96 accession exposed to cadmium pollution. Nitrate inhibition has been shown to have many effects, including a decrease in nodule number, nodule mass, and $\mathrm{N}_{2}$ fixation activity, as well as the acceleration of nodule senescence or disintegration; therefore, nitrate inhibition cannot be explained simply (Ohyama et al., 2012). The mechanisms of the initiation of lateral roots have been studied previously (Fukai et al., 2002) however, the regulation of primary and lateral root growth in relation to nodule growth in African yam bean has not yet been fully evaluated. Even so, Iranpour et al. (2016) reported that the application of cadmium did significantly decrease nodule fresh mass in Phaseolus vulgaris L. This previous report supports the findings of the present study which opine that the number of root nodules per plant reduced in all AYB accessions upon treatment. In addition, cadmium (Cd) treat-

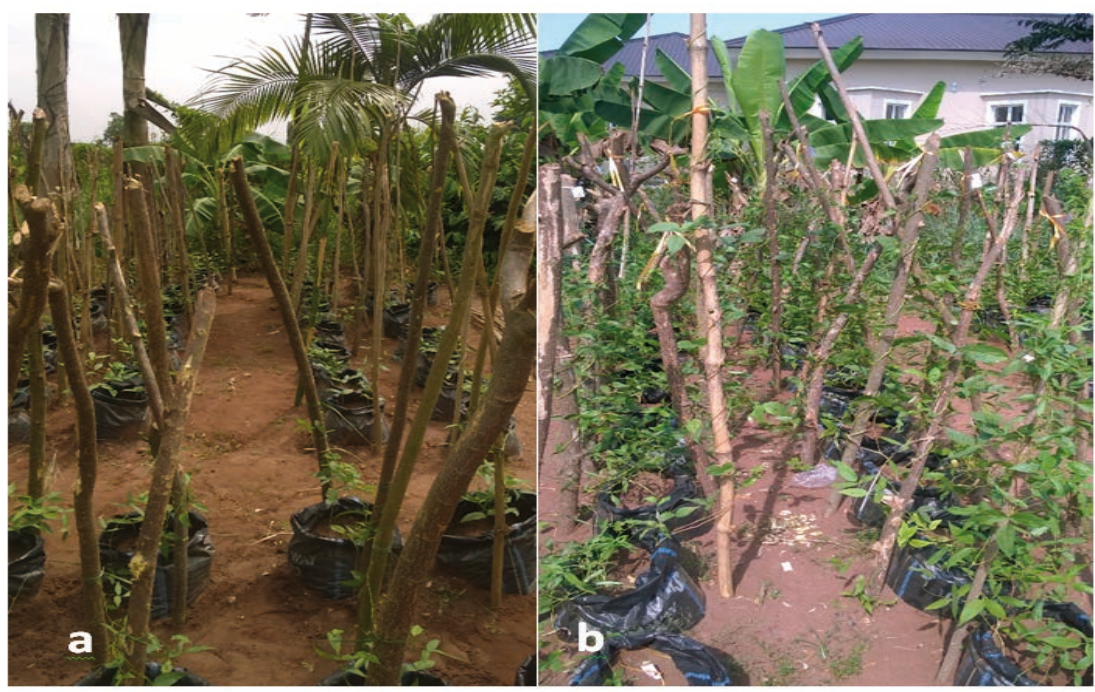

Figure 1: African yam bean genotypes at (a) 2 weeks and (b) 4 weeks after sowing 


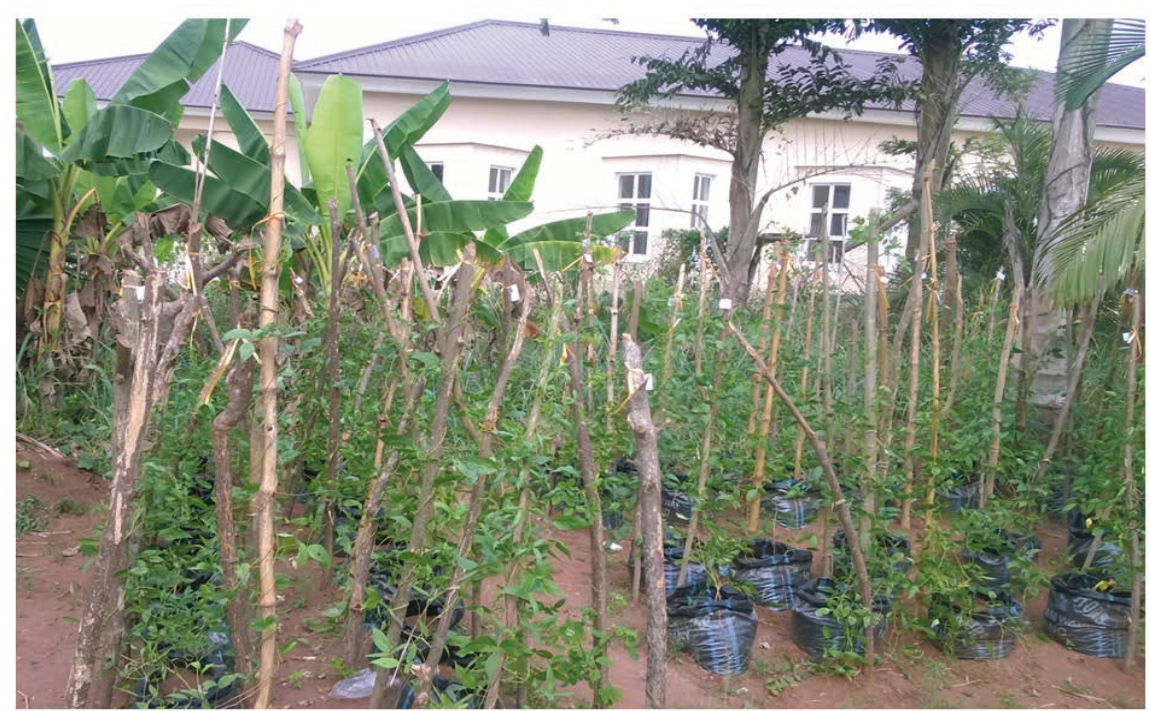

Figure 2: An overview of the experimental plot showing 6 week-old African yam bean plants

ment also caused a noticeable change in tuber yield of yield was observed in TSs-95 with $78.3 \%$ reduction TSs-96 (12.65 g - $4.11 \mathrm{~g})$. However, the most signifiin tuber yield compared to $71.5 \%$ and $61.4 \%$ decline cant effect of Cd contamination with respect to tuber detected in TSs-93 and TSs-89 in that order.

Table 3: Effects of treatment on above and below ground parameters of African yam bean at 20 weeks after sowing

\begin{tabular}{|c|c|c|c|c|c|c|c|c|c|}
\hline Treatment & $\begin{array}{l}\text { Shoot } \\
\text { length }(\mathrm{cm})\end{array}$ & $\begin{array}{l}\text { No. of } \\
\text { primary } \\
\text { branches }\end{array}$ & $\begin{array}{l}\text { No. leaves } \\
\text { plant }^{-1}\end{array}$ & $\begin{array}{l}\text { Root length } \\
(\mathrm{cm})\end{array}$ & $\begin{array}{l}\text { No. of pri- } \\
\text { mary root } \\
\text { branches }\end{array}$ & $\begin{array}{l}\text { No. of root } \\
\text { nodules per } \\
\text { plant }\end{array}$ & $\begin{array}{l}\text { Nodules } \\
\text { yield }(\mathrm{g})\end{array}$ & $\begin{array}{l}\text { Tuber } \\
\text { plant }^{-1}\end{array}$ & $\begin{array}{l}\text { Tuber } \\
\text { yield (g) }\end{array}$ \\
\hline TSs-87_U & $72.03^{\mathrm{h}}$ & $6.16^{g}$ & $38.3^{\mathrm{i}}$ & $26.06^{\mathrm{hi}}$ & $5.02^{\mathrm{e}}$ & $11.21^{\mathrm{e}}$ & $1.48^{\mathrm{ab}}$ & $4.03^{e}$ & $8.08^{\mathrm{g}}$ \\
\hline TSs-87_Cd & $63.70^{f}$ & $4.11^{\mathrm{de}}$ & $29.07^{\mathrm{d}}$ & $20.10^{\mathrm{d}}$ & $2.05^{\mathrm{a}}$ & $9.18^{\mathrm{d}}$ & $1.01^{\mathrm{a}}$ & $2.21^{\mathrm{b}}$ & $3.31^{\mathrm{abc}}$ \\
\hline TSs-89_U & $74.11^{\mathrm{j}}$ & $4.21^{\mathrm{de}}$ & $55.20^{\mathrm{m}}$ & $21.21^{\mathrm{e}}$ & $5.02^{\mathrm{e}}$ & $16.81^{\mathrm{h}}$ & $2.03^{\mathrm{bcd}}$ & $6.16^{\mathrm{f}}$ & $12.2^{\mathrm{i}}$ \\
\hline TSs-89_Cd & $63.24^{\mathrm{f}}$ & $4.04^{\mathrm{de}}$ & $36.11^{\mathrm{h}}$ & $12.30^{\mathrm{a}}$ & $3.4 c^{d}$ & $9.11^{\mathrm{d}}$ & $1.13^{\mathrm{a}}$ & $1.06^{\mathrm{a}}$ & $3.48^{\mathrm{abcd}}$ \\
\hline TSs-90_U & $80.03^{\mathrm{m}}$ & $4.08^{\mathrm{de}}$ & $42.13^{1}$ & $26.35^{\mathrm{i}}$ & $5.01^{\mathrm{e}}$ & $18.68^{\mathrm{i}}$ & $2.55 \mathrm{~d}^{\mathrm{ef}}$ & $3.21^{\mathrm{cd}}$ & $3.95^{\mathrm{cde}}$ \\
\hline TSs-90_Cd & $54.07^{c}$ & $2.52^{\mathrm{ab}}$ & $15.26^{\mathrm{b}}$ & $20.13^{\mathrm{d}}$ & $3.07^{b c}$ & $4.15^{\mathrm{a}}$ & $1.35^{\mathrm{a}}$ & $1.40^{\mathrm{a}}$ & $2.70^{\mathrm{a}}$ \\
\hline TSs-91_U & $56.07^{d}$ & $2.88^{\mathrm{b}}$ & $40.23^{j}$ & $27.06 j$ & $5.67^{\mathrm{e}}$ & $11.34^{\mathrm{ef}}$ & $1.55^{\mathrm{abc}}$ & $4.07^{\mathrm{e}}$ & $9.09^{\mathrm{h}}$ \\
\hline TSs-91_Cd & $42.96^{\mathrm{a}}$ & $2.66^{\mathrm{ab}}$ & $18.16^{c}$ & $23.03^{\mathrm{g}}$ & $4.08^{\mathrm{d}}$ & $5.27^{\mathrm{b}}$ & $0.95^{\mathrm{a}}$ & $1.10^{\mathrm{a}}$ & $4.65^{\mathrm{e}}$ \\
\hline TSs-92_U & $73.33^{\mathrm{i}}$ & $7.24^{\mathrm{h}}$ & $41.30^{\mathrm{k}}$ & $21.10^{\mathrm{e}}$ & $4.08^{\mathrm{d}}$ & $14.02^{\mathrm{g}}$ & $2.11^{\mathrm{cd}}$ & $3.86^{\mathrm{e}}$ & $9.10^{\mathrm{h}}$ \\
\hline TSs-92_Cd & $64.71^{\mathrm{g}}$ & $5.17^{\mathrm{f}}$ & $30.15^{\mathrm{e}}$ & $17.25^{c}$ & $7.01^{\mathrm{f}}$ & $13.67^{\mathrm{g}}$ & $1.00^{\mathrm{a}}$ & $2.06^{\mathrm{d}}$ & $3.70^{\mathrm{bcd}}$ \\
\hline TSs-93_U & $76.18^{\mathrm{k}}$ & $3.55^{\mathrm{cd}}$ & $56.46^{\mathrm{n}}$ & $28.01^{\mathrm{k}}$ & $7.68^{f}$ & $23.02 j$ & $3.05^{\mathrm{fg}}$ & $5.67^{\mathrm{f}}$ & $13.01^{j}$ \\
\hline TSs-93_Cd & $51.93^{\mathrm{b}}$ & $2.06^{\mathrm{a}}$ & $38.09^{i}$ & $22.05^{f}$ & $2.23^{\mathrm{a}}$ & $14.03 \mathrm{~g}$ & $1.22^{\mathrm{a}}$ & $3.00^{\mathrm{cd}}$ & $5.02^{\mathrm{f}}$ \\
\hline TSs-94_U & $82.53^{\mathrm{n}}$ & $6.27^{\mathrm{g}}$ & $33.39^{j}$ & $25.69^{f}$ & $5.01^{\mathrm{e}}$ & $19.01 \mathrm{i}$ & $2.89^{\text {efg }}$ & $3.54^{\text {de }}$ & $3.28^{\mathrm{abc}}$ \\
\hline TSs-94_Cd & $65.13^{g}$ & $6.06^{\mathrm{g}}$ & $15.10^{\mathrm{b}}$ & $21.36^{\mathrm{e}}$ & $2.27^{\mathrm{a}}$ & $14.50 \mathrm{~g}$ & $2.00^{\mathrm{bcd}}$ & $2.16^{\mathrm{b}}$ & $3.03^{\mathrm{ab}}$ \\
\hline TSs-95_U & $79.07^{1}$ & $4.52^{\mathrm{e}}$ & $40.20^{j}$ & $21.14^{\mathrm{e}}$ & $5.01^{\mathrm{e}}$ & $16.67 \mathrm{~h}$ & $2.44^{\mathrm{de}}$ & $8.18^{g}$ & $13.96^{\mathrm{k}}$ \\
\hline TSs-95_Cd & $52.10^{\mathrm{b}}$ & $3.06^{\mathrm{bc}}$ & $12.00^{\mathrm{a}}$ & $17.36^{c}$ & $3.33^{\mathrm{cd}}$ & $8.21 \mathrm{c}$ & $1.40^{\mathrm{a}}$ & $1.00^{\mathrm{a}}$ & $3.03^{\mathrm{ab}}$ \\
\hline TSs-96_U & $83.10^{\mathrm{n}}$ & $8.20^{\mathrm{i}}$ & $34.40^{\mathrm{g}}$ & $28.15^{\mathrm{k}}$ & $7.71^{\mathrm{f}}$ & $24.03 \mathrm{k}$ & $3.15^{g}$ & $6.00^{f}$ & $12.65^{\mathrm{ij}}$ \\
\hline TSs-96_Cd & $60.08^{e}$ & $5.18^{\mathrm{f}}$ & $15.01^{\mathrm{b}}$ & $14.38^{\mathrm{b}}$ & $2.51^{\mathrm{ab}}$ & $12.05 f$ & $1.00^{\mathrm{a}}$ & $2.70^{\mathrm{bc}}$ & $4.11^{\mathrm{de}}$ \\
\hline$\underline{p}$-value & $1.46 \times 10^{-51}$ & $1.17 \times 10^{-21}$ & $1.89 \times 10^{-57}$ & $2.11 \times 10^{-37}$ & $4.13 \times 10^{-20}$ & $4.17 \times 10^{-36}$ & $3.44 \times 10^{-34}$ & $3.53 \times 10^{-24}$ & $1.18 \times 10^{-32}$ \\
\hline
\end{tabular}

Means with the same alphabetic superscripts on the same column do not differ from each other $(p>0.05) . \mathrm{U}=\mathrm{Unexposed}$, Cd $=\mathrm{Cd}$-exposed. 


\subsection{EFFECT OF CADMIUM POLLUTION ON YIELD OF AYB}

Considering the consequence of cadmium (Cd) treatment on reproductive capacity of African yam bean, results showed that there were observable changes between Cd-exposed and unexposed AYB accessions with regard to days to flower bud initiation. It took 35 days for development of flower bud to be initiated in the unexposed TSs- 87 plant, while that of the Cd-exposed TSs- 87 plant occurred on the $36^{\text {th }}$ day (Table 4 ). Where flower bud was initiated in unexposed TSs- 89 at $36^{\text {th }}$ day after sowing (DAS), the same initiation occurred in Cd-exposed TSs-89 a day before (35). This has great implication on the total productivity of a plant, in that a plant yield is a function of the number of flower it produces. Anjum et al. (2008) reported that exposure to $\mathrm{Cd}$ results in reduced plant growth and biomass in Brassica campestris L. respectively. This occurs when $\mathrm{Cd}$ absorbed through the root system significantly inhibits plant growth by interfering with water and mineral uptake, photosynthesis and nitrogen metabolism. This confirms the results obtained in the present study as the yield of African yam bean (AYB) was significantly reduced in cadmium-Cd-exposed AYB accession, particularly with regard to biomass production. Conversely, in the work carried out by Kavvadias et al. (2012) it was observed that Cd contamination showed no significant changes in biomass of parsley. However, it is noteworthy that in Kavvadias et al. (2012), the study was conducted with $100 \mathrm{mg} \mathrm{kg}^{-1}$ of $\mathrm{Cd}$ as the highest concentration unlike the presence study in which the concentration of $\mathrm{Cd}$ in the soil was $240 \mathrm{mg} \mathrm{kg}^{-1}$. This supports the findings of Paschalidis et al. (2013) whose studies revealed that cadmium could cause reductions in yield of plants.

Effects of cadmium pollution on pod maturation of African yam bean (AYB) was studied and it was observed that first pod was formed between $58-68$ days in unexposed AYB accessions while first pod formation in plants under the influence of cadmium exposure occurred between $60-70$ days. Pod formation was relatively faster in unexposed plants accessions than in Cd-exposed ones. Unexposed TSs-87 and TSs-

Table 4: Effects of treatment on reproductive capacity of African yam bean (DAS)

\begin{tabular}{|c|c|c|c|c|c|c|c|c|c|}
\hline Treatment & $\begin{array}{l}\text { Length of } \\
\text { peduncle } \\
(\mathrm{cm})\end{array}$ & Days to FBI & $\begin{array}{l}\text { Days to } \\
\text { I } 50 \% \text { FBI }\end{array}$ & $\begin{array}{l}\text { Flower bud } \\
\text { size }(\mathrm{mm})\end{array}$ & $\begin{array}{l}\text { No. of flow- } \\
\text { ers plant }^{-1}\end{array}$ & $\begin{array}{l}\text { Flowering } \\
\text { - duration } \\
\text { (DAS) }\end{array}$ & $\begin{array}{l}\text { Days to } 1^{\text {st }} \\
\text { pod forma- } \\
\text { tion (DAS) }\end{array}$ & $\begin{array}{l}\text { Days to } \\
50 \% \text { matu- } \\
\text { rity (DAS) }\end{array}$ & $\begin{array}{l}\text { Maturity } \\
\text { - period } \\
\text { (Days) }\end{array}$ \\
\hline TSs-87_U & $2.95^{\mathrm{f}}$ & $35.05^{\text {cdef }}$ & $43.01^{\mathrm{b}}$ & $0.88 \mathrm{~d}^{\mathrm{ef}}$ & $23.03^{\mathrm{cd}}$ & $21.01^{\mathrm{f}}$ & $58.04^{\mathrm{a}}$ & $75.07^{\mathrm{b}}$ & $20.00^{\mathrm{e}}$ \\
\hline TSs-87_Cd & $1.90^{\mathrm{bc}}$ & $35.81^{\text {efg }}$ & $42.28^{\mathrm{b}}$ & $0.49^{\mathrm{a}}$ & $21.11^{b c}$ & $14.66^{\mathrm{e}}$ & $60.10^{\mathrm{ef}}$ & $82.30^{\mathrm{ef}}$ & $26.04^{j}$ \\
\hline TSs-89_U & $2.17^{\text {cde }}$ & $36.67^{g}$ & $42.37^{\mathrm{b}}$ & $0.82^{\text {cde }}$ & $27.67^{\mathrm{e}}$ & $23.66^{\mathrm{h}}$ & $60.03^{\text {def }}$ & $76.37^{\mathrm{c}}$ & $18.89^{c d}$ \\
\hline TSs-89_Cd & $1.13^{\mathrm{a}}$ & $35.05^{\mathrm{cdef}}$ & $41.00^{\mathrm{b}}$ & $0.55^{\mathrm{a}}$ & $20.08^{\mathrm{b}}$ & $12.28^{\mathrm{a}}$ & $61.40^{\text {gh }}$ & $82.70^{\text {ef }}$ & $22.38^{\mathrm{g}}$ \\
\hline TSs-90_U & $2.11^{\text {cde }}$ & $33.67^{\mathrm{b}}$ & $39.03^{\mathrm{b}}$ & $0.97^{\text {efg }}$ & $33.05^{\mathrm{f}}$ & $20.33^{\mathrm{f}}$ & $59.26^{\mathrm{cd}}$ & $76.18^{c}$ & $18.15^{\mathrm{bc}}$ \\
\hline TSs-90_Cd & $1.13^{\mathrm{a}}$ & $34.23 \mathrm{bcd}$ & $40.03^{\mathrm{b}}$ & $0.76^{\mathrm{bcd}}$ & $23.04^{\mathrm{cd}}$ & $12.67^{\mathrm{ab}}$ & $60.77^{\mathrm{fg}}$ & $83.05 f$ & $21.14^{\mathrm{f}}$ \\
\hline TSs-91_U & $2.61^{\mathrm{ef}}$ & $34.68 \mathrm{bcde}$ & $42.34^{\mathrm{b}}$ & $1.06^{\mathrm{gh}}$ & $23.07^{\mathrm{cd}}$ & $18.01^{\mathrm{e}}$ & $59.34^{\text {cde }}$ & $75.72^{\mathrm{bc}}$ & $19.01^{\mathrm{cd}}$ \\
\hline TSs-91_Cd & $1.41^{\mathrm{ab}}$ & $36.03 \mathrm{fg}$ & $44.35^{\mathrm{b}}$ & $0.94^{\mathrm{efg}}$ & $20.15^{\mathrm{b}}$ & $12.16^{\mathrm{a}}$ & $62.08^{\mathrm{h}}$ & $82.04^{\mathrm{e}}$ & $23.153^{\mathrm{gh}}$ \\
\hline TSs-92_U & $2.11^{\text {cde }}$ & $34.01 b c$ & $39.03^{\mathrm{b}}$ & $0.97^{\mathrm{efg}}$ & $33.05^{\mathrm{f}}$ & $20.33^{\mathrm{f}}$ & $59.03^{c}$ & $78.36^{\mathrm{d}}$ & $18.00^{\mathrm{b}}$ \\
\hline TSs-92_Cd & $1.21^{\mathrm{a}}$ & $35.03 \mathrm{cdef}$ & $29.10^{\mathrm{a}}$ & $0.75^{\mathrm{bcd}}$ & $20.34^{\mathrm{b}}$ & $13.01^{\mathrm{b}}$ & $62.05^{\mathrm{h}}$ & $84.36^{\mathrm{g}}$ & $23.08^{\mathrm{gh}}$ \\
\hline TSs-93_U & $3.00^{\mathrm{f}}$ & $35.34 \mathrm{def}$ & $42.04^{\mathrm{b}}$ & $1.01^{\mathrm{fgh}}$ & $19.17^{\mathrm{b}}$ & $22.35^{\mathrm{g}}$ & $58.72^{\mathrm{b}}$ & $68.35^{\mathrm{a}}$ & $16.67^{\mathrm{a}}$ \\
\hline TSs-93_Cd & $2.10^{\text {cde }}$ & $33.85 b$ & $40.01^{\mathrm{b}}$ & $0.64^{\mathrm{ab}}$ & $14.54^{\mathrm{a}}$ & $17.68^{\mathrm{de}}$ & $61.44^{\mathrm{gh}}$ & $82.45^{\text {ef }}$ & $22.44^{\mathrm{g}}$ \\
\hline TSs-94_U & $2.50^{\mathrm{de}}$ & $35.14 \mathrm{def}$ & $44.00^{\mathrm{b}}$ & $0 \mathrm{~s} .82^{\text {cde }}$ & $28.01^{\mathrm{e}}$ & $23.66^{\mathrm{h}}$ & $57.71^{\mathrm{a}}$ & $75.07^{\mathrm{b}}$ & $20.34^{\mathrm{ef}}$ \\
\hline TSs-94_Cd & $1.95^{\mathrm{bcd}}$ & 35.37def & $43.68^{\mathrm{b}}$ & $0.52^{\mathrm{a}}$ & $24.34^{\mathrm{d}}$ & $17.15^{\mathrm{d}}$ & $61.08^{g}$ & $84.06^{g}$ & $26.91^{\mathrm{k}}$ \\
\hline TSs-95_U & $2.83^{\text {cde }}$ & $35.05 \mathrm{cdef}$ & $43.34^{\mathrm{b}}$ & $0.78^{\mathrm{bcd}}$ & $23.03^{\mathrm{cd}}$ & $20.68^{\mathrm{f}}$ & $67.02^{\mathrm{i}}$ & $82.34^{\mathrm{ef}}$ & $19.01^{\mathrm{cd}}$ \\
\hline TSs-95_Cd & $1.42^{\mathrm{ab}}$ & $36.71 \mathrm{~g}$ & $44.00^{\mathrm{b}}$ & $0.56^{\mathrm{a}}$ & $20.38^{\mathrm{b}}$ & $14.00^{c}$ & $70.99^{1}$ & $93.27^{\mathrm{h}}$ & $25.08^{\mathrm{i}}$ \\
\hline TSs-96_U & $3.00^{\mathrm{f}}$ & $35.67 \mathrm{efg}$ & $42.37^{\mathrm{b}}$ & $1.15^{\mathrm{h}}$ & $19.17^{\mathrm{b}}$ & $22.35^{\mathrm{g}}$ & $68.08^{\mathrm{k}}$ & $83.03^{\mathrm{f}}$ & $19.14^{\mathrm{d}}$ \\
\hline TSs-96_Cd & $2.14^{\text {cde }}$ & $30.55 a$ & $40.76^{\mathrm{b}}$ & $0.71 b^{c}$ & $19.01^{\mathrm{b}}$ & $18.07^{\mathrm{e}}$ & $70.45^{1}$ & $93.51^{\mathrm{h}}$ & $23.78^{\mathrm{h}}$ \\
\hline$\underline{p \text {-value }}$ & $2.8 \times 10^{-10}$ & $4.4 \times 10^{-12}$ & $1.76 \times 10^{-1}$ & $6.18 \times 10^{-12}$ & $7.25 \times 10^{-19}$ & $1.17 \times 10^{-32}$ & $2.68 \times 10^{-32}$ & $7.38 \times 10^{-37}$ & $2.14 \times 10^{-25}$ \\
\hline
\end{tabular}

FBI $=$ Flower bud initiation, DAS $=$ Days after sowing. $\mathrm{U}=$ Unexposed, $\mathrm{Cd}=\mathrm{Cd}$-exposed.

Means with the same alphabetic superscripts on the same column do not differ from each other $(p>0.05)$. 
Table 5: Effects of treatment on yield parameters of African yam bean

\begin{tabular}{|c|c|c|c|c|c|c|c|c|c|}
\hline Treatment & Seed cavity & $\begin{array}{l}\text { Locules } \\
\text { pod }^{-1}\end{array}$ & $\begin{array}{l}\text { Pod length } \\
(\mathrm{cm})\end{array}$ & $\begin{array}{l}\text { Single pod } \\
\text { mass }(\mathrm{g})\end{array}$ & $\begin{array}{l}\text { Pods pe- } \\
\text { duncle }^{-1}\end{array}$ & $\begin{array}{l}\text { No. of pods } \\
\text { plant }^{-1}\end{array}$ & $\begin{array}{l}\text { Seed No. } \\
\text { pod }^{-1}\end{array}$ & $\begin{array}{l}\text { Seed mass } \\
\text { pod }^{-1}\end{array}$ & $\begin{array}{l}\text { Plant yield } \\
\left(\mathrm{kg} \mathrm{m}^{-2}\right)\end{array}$ \\
\hline TSs-87_U & $\mathrm{Pr}$ & $7.05^{\mathrm{cd}}$ & $6.04^{c}$ & $3.70^{\mathrm{bcd}}$ & $2.06^{\mathrm{ab}}$ & $12.07^{\mathrm{e}}$ & $6.05^{\mathrm{a}}$ & $2.97^{\mathrm{cd}}$ & $0.11^{\mathrm{b}}$ \\
\hline TSs-87_Cd & $\operatorname{Pr}$ & $6.25^{\mathrm{ab}}$ & $5.41^{\mathrm{b}}$ & $3.37^{\mathrm{abc}}$ & $1.39^{\mathrm{a}}$ & $6.01^{\mathrm{a}}$ & $6.14^{\mathrm{ab}}$ & $2.41^{\mathrm{ab}}$ & $0.04^{\mathrm{a}}$ \\
\hline TSs-89_U & $\operatorname{Pr}$ & $7.19^{\mathrm{cd}}$ & $6.15^{c}$ & $4.24^{\mathrm{de}}$ & $3.21^{\mathrm{c}}$ & $12.34^{\mathrm{f}}$ & $8.08^{\mathrm{fg}}$ & $3.25^{\mathrm{d}}$ & $0.13^{\mathrm{b}}$ \\
\hline TSs-89_Cd & $\operatorname{Pr}$ & $5.70^{\mathrm{a}}$ & $5.03^{\mathrm{b}}$ & $3.05^{\mathrm{ab}}$ & $2.42^{\mathrm{bc}}$ & $6.09^{\mathrm{a}}$ & $6.39^{\mathrm{abc}}$ & $2.09^{\mathrm{ab}}$ & $0.03^{\mathrm{a}}$ \\
\hline TSs-90_U & $\operatorname{Pr}$ & $7.39^{\mathrm{de}}$ & $5.21^{\mathrm{b}}$ & $4.17^{\mathrm{de}}$ & $2.56^{\mathrm{bc}}$ & $13.51^{\mathrm{h}}$ & $7.12^{\mathrm{cd}}$ & $3.08^{\mathrm{cd}}$ & $0.14^{\mathrm{b}}$ \\
\hline TSs-90_Cd & $\operatorname{Pr}$ & $7.37^{\mathrm{de}}$ & $4.03^{\mathrm{a}}$ & $4.02^{\text {cde }}$ & $2.01^{\mathrm{ab}}$ & $7.45^{\mathrm{cd}}$ & $6.09^{\mathrm{a}}$ & $2.05^{\mathrm{a}}$ & $0.04^{\mathrm{a}}$ \\
\hline TSs-91_U & $\operatorname{Pr}$ & $7.11^{\mathrm{cd}}$ & $6.07^{c}$ & $3.70^{\mathrm{bcd}}$ & $2.09^{\mathrm{ab}}$ & $12.06^{\mathrm{ef}}$ & $6.24^{\mathrm{ab}}$ & $2.60^{\mathrm{bc}}$ & $0.11^{\mathrm{b}}$ \\
\hline TSs-91_Cd & $\operatorname{Pr}$ & $5.59^{\mathrm{a}}$ & $5.15^{\mathrm{b}}$ & $2.74^{\mathrm{a}}$ & $1.40^{\mathrm{a}}$ & $6.15^{\mathrm{a}}$ & $6.34^{\mathrm{abc}}$ & $2.01^{\mathrm{a}}$ & $0.03^{\mathrm{a}}$ \\
\hline TSs-92_U & $\operatorname{Pr}$ & $6.90^{\mathrm{bc}}$ & $6.31^{\mathrm{c}}$ & $3.91^{\mathrm{cde}}$ & $3.21^{\mathrm{c}}$ & $13.14^{\mathrm{gh}}$ & $7.44^{\mathrm{def}}$ & $3.05^{\mathrm{cd}}$ & $0.12^{\mathrm{a}}$ \\
\hline TSs-92_Cd & $\operatorname{Pr}$ & $6.10^{\mathrm{a}}$ & $5.07^{\mathrm{b}}$ & $3.03^{\mathrm{ab}}$ & $2.06^{\mathrm{ab}}$ & $8.08^{\mathrm{d}}$ & $6.36^{\mathrm{abc}}$ & $2.05^{\mathrm{a}}$ & $0.06^{\mathrm{a}}$ \\
\hline TSs-93_U & $\operatorname{Pr}$ & $8.14^{\mathrm{e}}$ & $5.93^{c}$ & $5.04^{\mathrm{f}}$ & $2.86^{\mathrm{bc}}$ & $12.54^{\mathrm{fg}}$ & $8.01^{\mathrm{efg}}$ & $3.11^{\mathrm{cd}}$ & $0.19^{c}$ \\
\hline TSs-93_Cd & $\operatorname{Pr}$ & $7.03^{\mathrm{cd}}$ & $4.02^{\mathrm{a}}$ & $4.11^{\mathrm{cde}}$ & $2.11^{\mathrm{ab}}$ & $6.70^{\mathrm{ab}}$ & $6.08^{\mathrm{a}}$ & $2.13^{\mathrm{ab}}$ & $0.05^{\mathrm{a}}$ \\
\hline TSs-94_U & $\operatorname{Pr}$ & $8.48^{\mathrm{e}}$ & $5.32^{\mathrm{b}}$ & $4.59^{\mathrm{e}}$ & $2.57^{\mathrm{bc}}$ & $13.74^{\mathrm{h}}$ & $6.94^{\mathrm{bcd}}$ & $3.02^{\mathrm{cd}}$ & $0.14^{\mathrm{b}}$ \\
\hline TSs-94_Cd & $\operatorname{Pr}$ & $7.07^{\mathrm{cd}}$ & $4.10^{\mathrm{a}}$ & $4.12^{\text {cde }}$ & $2.38^{\mathrm{bc}}$ & $6.15^{\mathrm{a}}$ & $7.19^{\mathrm{d}}$ & $2.15^{\mathrm{ab}}$ & $0.05^{\mathrm{a}}$ \\
\hline TSs-95_U & $\operatorname{Pr}$ & $9.08^{f}$ & $5.17^{\mathrm{b}}$ & $5.15^{\mathrm{e}}$ & $2.50^{\mathrm{bc}}$ & $11.47^{\mathrm{e}}$ & $8.58^{\mathrm{g}}$ & $3.21^{\mathrm{d}}$ & $0.13^{\mathrm{b}}$ \\
\hline TSs-95_Cd & $\operatorname{Pr}$ & $7.36^{\mathrm{cd}}$ & $4.17^{\mathrm{a}}$ & $4.04^{\text {cde }}$ & $2.09^{\mathrm{ab}}$ & $6.01^{\mathrm{a}}$ & $6.03^{\mathrm{a}}$ & $2.08^{\mathrm{ab}}$ & $0.03^{\mathrm{a}}$ \\
\hline TSs-96_U & $\operatorname{Pr}$ & $9.04^{\mathrm{f}}$ & $5.08^{\mathrm{a}}$ & $5.05^{\mathrm{f}}$ & $2.84^{\mathrm{bc}}$ & $13.74^{\mathrm{h}}$ & $7.28^{\mathrm{de}}$ & $3.35^{\mathrm{d}}$ & $0.13^{\mathrm{b}}$ \\
\hline TSs-96_Cd & $\operatorname{Pr}$ & $7.07^{\mathrm{cd}}$ & $4.04^{\mathrm{a}}$ & $4.02^{\text {cde }}$ & $2.06^{\mathrm{ab}}$ & $6.99^{\mathrm{bc}}$ & $6.08^{\mathrm{a}}$ & $2.08^{\mathrm{ab}}$ & $0.05^{\mathrm{a}}$ \\
\hline $\mathrm{p}$-value & & $3.68 \times 10^{-12}$ & $2.57 \times 10^{-14}$ & $4.36 \times 10^{-8}$ & $7.82 \times 10^{-4}$ & $1.11 \times 10^{-10}$ & $3.27 \times 10^{-9}$ & $6.21 \times 10^{-9}$ & $4.12 \times 10^{-11}$ \\
\hline
\end{tabular}

Means with the same alphabetic superscripts on the same column do not differ from each other $(p>0.05) . \mathrm{U}=\mathrm{Unexposed}$, Cd $=\mathrm{Cd}$-exposed. $\operatorname{Pr}=$ Present

93 produced their first pod in 58 days whereas their Cd-exposed equivalence showed pod formation in 60 and 61 days respectively. Similar outcome was observed with regard to days to $50 \%$ maturity. It took 93 days for half of the pods in Cd-exposed TSs-96 to attained maturity as against 82 days observed in Cd-exposed TSs-87, TSs-89, TSs-91, and TSs-93. Previous investigations have shown that cadmium induces significant differences in pod characteristics of legumes (Rout et al., 1999). Ghani (2010) reported that accumulation of $\mathrm{Cd}^{2+}$ in plant parts of mungbean (Vigna radiata (L.) R. Wilczek altered the number of pods per plant, average pod length, and fresh and dry mass of pods per plants. Evidence from present study proved that cadmium $(\mathrm{Cd})$ contamination has no effect on seed cavity (Table 5) on ridges on pod in both Cd-exposed and unexposed plants as both showed cavity on ridges. There were 7.05 locules per pod in unexposed TSs-87 as against 6.25 in the Cd-exposed accession. Number of locules recorded for unexposed TSs-89, TSs-90, and TSs-91 was fairly similar at 7.19, 7.39, and 7.11 correspondingly whereas their Cd-exposed complements had 5.70, 7.37, and 5.59 in that order. Observably, there was no prominent dif- ference in locules number in TSs-90 for both Cd-exposed and unexposed plants.

In terms of effects of cadmium pollution on pod production in African yam bean, results showed that number of pods per plant decreased with incidence of cadmium exposure. There was at least $50 \%$ reduction in the number of pods in all Cd-exposed accessions when compared to their unexposed counterparts. Number of pods per plant reduced from 12 to 6 in unexposed and Cd-exposed TSs-87, TSs-89, TSs-91, and TSs-93 in that order. Cd-exposed TSs-95 was most affected by cadmium in relation to plant yield as it stood at $0.03 \mathrm{~kg} \mathrm{~m}^{-2}$. Cd-exposed TSs-92, TSs-93, TSs-94, and TSs-96 were fairly tolerant to cadmium pollution as their yield was higher than other Cd-exposed counterparts in the test plant. Similar effects were observed by Ghani (2010) when mungbean was exposed to cadmium pollution.

\subsection{EFFECT ON PHYSIOLOGICAL PARAMETERS}

At 42 days after sowing, the effects of cadmium pollution on some pigmentation parameters of emer- 
gents of African yam bean was studied and results showed that the amount of chlorophyll-a (Chl-a) decreased in Cd-exposed plants compared to the value in unexposed category (Table 6). It was noticed that in the face of cadmium pollution, Cd-exposed TSs-87, TSs- 89 , and TSs- 96 have similar quantity of chl-a $(0.13$ $\mathrm{mg} \mathrm{g}^{-1}$ ) although their unexposed equivalence differ at $0.09 \mathrm{mg} \mathrm{g}^{-1}, 0.12 \mathrm{mg} \mathrm{g}^{-1}$, and $0.11 \mathrm{mg} \mathrm{g}^{-1}$ in that order. Nevertheless, it was observed that the amount of Chl-b in both Cd-exposed and unexposed TSs-90 remained the same at $0.14 \mathrm{mg} \mathrm{g}^{-1}$ regardless of cadmium pollution. Cadmium usually attack protein by disrupting the conformation of the molecules through its affinity for sulfhydryl and carboxylic groups (Gonçalves et al., 2009). Furthermore, chlorophyll-a and chlorophyll-b contents showed significant decline at the applications of $\mathrm{Cd}$ and the results were in consonance with earlier reports where $\mathrm{Cd}$ inhibited the biosynthesis of chlorophyll and generated a kind of senescence (Qian et al., 2009). Nada et al. (2007) reported that Cd stress decreased chlorophyll content in leaf of almond (Prunus dulcis L.) seedling. Consequently, chlorophyll pigments seem to be one of the main reasons of heavy-metal injury in plants.

Concerning the carotenoids co ntent in test plants during the present study, there was an increase as occasioned by cadmium stress. The amount of carotenoids increased from $1123 \mathrm{mg} \mathrm{g}^{-1}$ in unexposed TSs-89 to $1173 \mathrm{mg} \mathrm{g}^{-1}$ in the Cd-exposed counterpart. The increase in carotenoids was due to the oxidative stress triggered by the presence of $\mathrm{Cd}^{2+}$ in the test plant as these isoprenoid compounds have been shown to act as signaling molecules during oxidative stress. Ramel et al. (2012b) reported a significant increase in b-carotene when Arabidopsis thaliana (L.) Heynh. was exposed to photooxidative stress. This is contrary to the findings of Paunov et al., 2018 who reported a decrease in carotenoid concentration when durum wheat was exposed to Cd stress. It was observed that in some accessions of AYB, tocopherol content increased after exposure to cadmium pollution whereas in others the reverse was the case. Tocopherol level decreased from $1.80 \mathrm{mg} \mathrm{g}^{-1}$ in unexposed TSs-87 to $1.63 \mathrm{mg} \mathrm{g}^{-1}$ in the Cd-exposed accession. Similar observation was made for TSs-89, TSs-90, TSs-93, and TSs-94 in which tocopherol level reduced from $0.82-0.65 \mathrm{mg} \mathrm{g}^{-1}, 0.14-0.08 \mathrm{mg} \mathrm{g}^{-1}, 1.72$ - $1.36 \mathrm{mg} \mathrm{g}^{-1}$, and $1.72-1.45 \mathrm{mg} \mathrm{g}^{-1}$ correspondingly. In TSs-95 and TSs-96 that were not subjected to cadmium stress, the concentration of tocopherol was 1.11 $\mathrm{mg} \mathrm{g}^{-1}$ and $0.54 \mathrm{mg} \mathrm{g}^{-1}$ respectively, and after exposure to cadmium pollution, concentration increased to $1.74 \mathrm{mg}$ $\mathrm{g}^{-1}$ and $2.00 \mathrm{mg} \mathrm{g}^{-1}$ in that order. Studies have shown that plant tissues differ a great deal in their tocopherol com- position (Munne-Bosch \& Alegre, 2002). This explains the discrepancy in tocopherol content as observed in the present study. In addition, based on the findings of Munne-Bosch (2005), plants with net loss of tocopherol are described as being sensitive to the prevalent stressor. This statement supports the suggestion of the present study that TSs-89, when compared across the board in all ramifications, shows high sensitivity to $\mathrm{Cd}$ contamination.

Interference with assimilation of nitrate nitrogen, due to cadmium pollution, was observed in Cd-exposed TSs-87 accession of African yam bean (AYB) including other accessions (Table 6). Concentration of nitrate nitrogen reduced from 453 in unexposed TSs- 87 to 100.25 in the Cd-exposed plant. This showed that Cd impeded nitrogen uptake in the Cd-exposed TSs-87. Gouia et al. (2000) revealed that treating bean with $50 \mu \mathrm{M} \mathrm{Cd}$ for $10 \mathrm{~h}$ reduced total nitrate uptake by $20 \%$ compared to control plants. They further observed that the decrease was higher at $12 \%$ of nitrate uptake in control plants with $100 \mu \mathrm{M} \mathrm{Cd}$. Unlike the aforementioned accession, it was observed that nitrate nitrogen level increased from 346.33 in unexposed TSs- 86 to 433.58 in the stress accession. The present study suspects that TSs- 86 has a metabolic shunt that prevent excess Cd uptake, thus allowing for increased nitrogen uptake in the face of Cd pollution. Earlier studies by Zhang et al. (2014) reported that ample nitrogen uptake inhibits $\mathrm{Cd}$ uptake through GSH pathway. Level of nitrate nitrogen in unexposed TSs-90 stood at 963.95 while cadmium treated counterpart showed lesser value at 336.78. Reduction in nitrate nitrogen in Cd-exposed TSs-91 was alarming. It reduced from 337.11 in unexposed accession to 77.11 in Cd-exposed plant. Effects of cadmium exposure on the concentration of nitrate nitrogen were more prominent in TSs-91 compared to other AYB considered during the investigation. With regard to ability to assimilate nitrate nitrogen under cadmium stress, TSs-96 showed greater tolerance than any other accession as the Cdexposed TSs-96 showed nitrate nitrogen of 566.56 as compared to 616.29 in the unexposed counterpart. Incidence of cadmium contamination resulted to change in ammonium nitrogen content of AYB accessions (Mokhele et al., 2012).

Table 7 shows a presentation of plant growth indices as affected by plant's exposure to treatments at 20 WAS. Results showed that leaf area index (LAI) increased in some AYB accessions while others experienced a decreased from Cd-exposed to unexposed plants and vice versa. According to the reports by Paunov et al. (2018), plants do not show general growth pattern in response to cadmium stress. They observed that shoot/root length ratio in Pfaffia glomerata (Spreng.) 


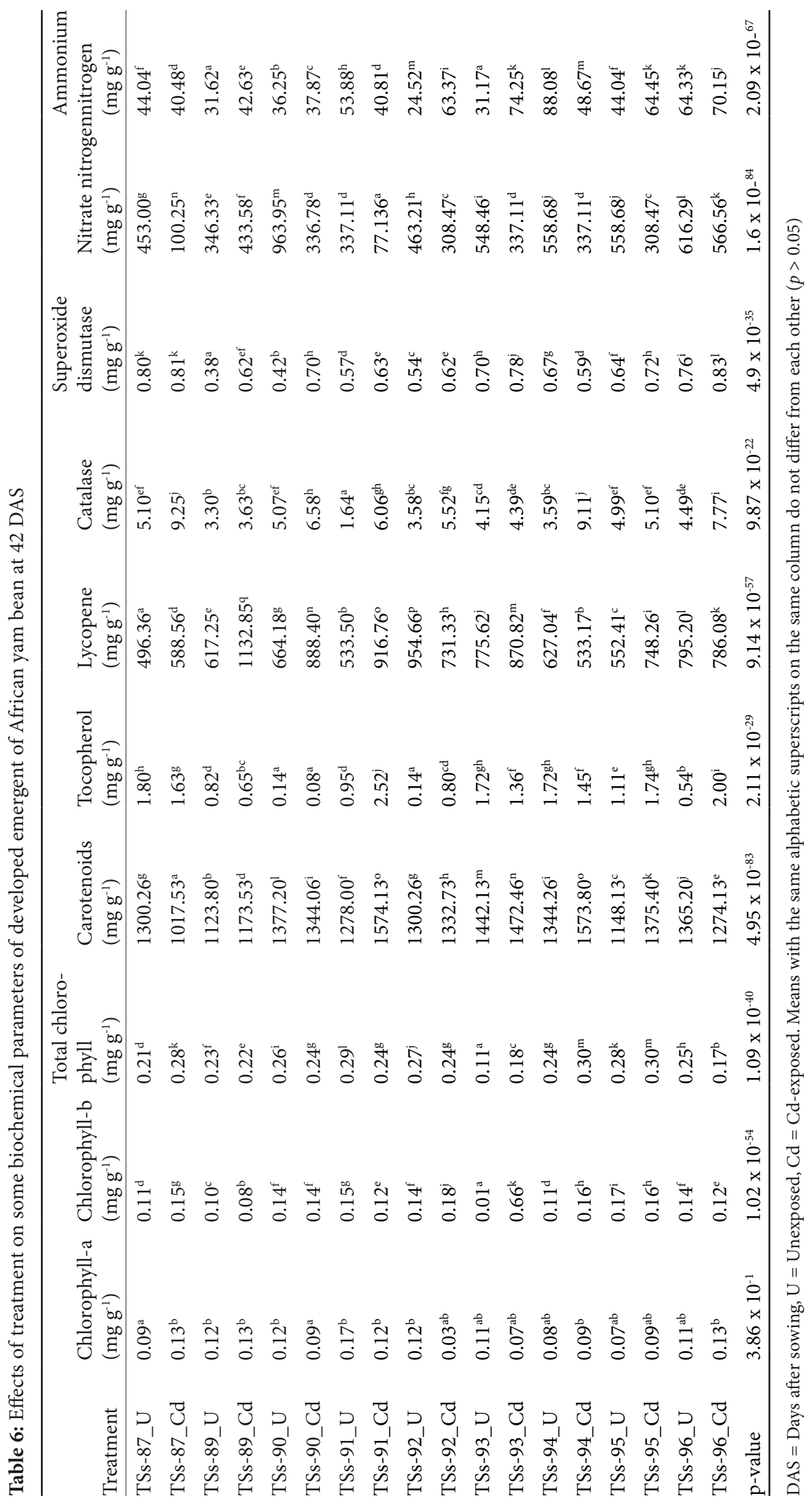


Pedersen when exposed to $20 \mu \mathrm{M}$ Cd, increased significantly but there was only slight increment when after exposure to more than $20 \mu \mathrm{M}$. This explains why there was no general pattern in leaf area index in the present study. In comparing Cd-exposed and unexposed AYB accessions, LAI increased by 0.01 in TSs- 89 and TSs92 , as well as decreased in TSs- 87 by the same margin. LAI in unexposed and Cd-exposed TSs-95 and TSs-96 are comparable as there was increase from $0.03-0.07$ in both plant accessions correspondingly. There was general decline in relative growth rate when cadmium Cd-exposed plants were examined alongside the unexposed plants. The highest reduction in plant dry mass production occurred in Cd-exposed TSs-96 at 752.81 . Observably, plant dry mass production reduced by 23.33 between Cd-exposed and unexposed TSs-90. In addition, cadmium contamination caused a decrease in plant basal area in Cd-exposed accessions of AYB. Similar results were reported by Thakur and Singh (2014) after they exposed soybean to different concentrations of Cd.

In determining the effects of cadmium pollution on plant dry matter accumulation of African yam bean at 20 weeks after planting, results showed a general decline in overall foliar yield of AYB accessions. As recorded in Table 7, overall foliar yield range between $15.22-34.21 \mathrm{~g}$ in plants that were not exposed to cadmium, whereas foliar yield in Cd-exposed plants ranged from $10.06-25.32 \mathrm{~g}$. There was $5.16 \mathrm{~g}$ reduction in overall foliar yield between Cd-exposed and unexposed TSs-87 while that of TSs-91 was $5.83 \mathrm{~g}$. Overall, foliar yield reduced from $19.66 \mathrm{~g}$ in unexposed TSs-89 to $18.07 \mathrm{~g}$ in Cd-exposed TSs-87. Estimation of plant dry mass showed that incidence of cadmium stress significantly reduced plant dry mass in all accessions of AYB. Up to $50 \%$ reduction in plant dry mass was observed in TSs-89, TSs-92, and TSs-95. Previous studies reported similar trend with respect to plant exposure to elevated cadmium concentration. Skrebsky et al. (2008) confirmed a reduction in shoot and total dry mass of Pfaffia glomerata (Spreng.) Pedersen [es] when exposed to $80 \mu \mathrm{M}$ of $\mathrm{Cd}$. Increase in dry mass of durum wheat was inhibited by approximately $50 \%$ after exposure to cadmium (Paunov et al., 2018).

Figure 3 shows the level of accumulation of cadmium in leaf of developed emergent of African yam

Table 7: Presentation of plant growth indices as affected by plant's exposure to treatments at 20 weeks after sowing

\begin{tabular}{|c|c|c|c|c|c|c|c|c|c|}
\hline Treatment & $\begin{array}{l}\text { leaf area } \\
\text { index }\end{array}$ & $\begin{array}{l}\text { relative } \\
\text { growth rate }\end{array}$ & $\begin{array}{l}\text { net assimi- } \\
\text { lation rate }\end{array}$ & $\begin{array}{l}\text { Crop } \\
\text { growth rate }\end{array}$ & $\begin{array}{l}\text { plant dry } \\
\text { mass pro- } \\
\text { duction }\end{array}$ & $\begin{array}{l}\text { Overall } \\
\text { foliar yield } \\
\text { (g) }\end{array}$ & $\begin{array}{l}\text { Plant dry } \\
\text { mass (g) }\end{array}$ & $\begin{array}{l}\text { Root dry } \\
\text { mass (g) }\end{array}$ & $\begin{array}{l}\text { Shoot:Root } \\
\text { Ratio }\end{array}$ \\
\hline TSs-87_U & $0.03^{\mathrm{a}}$ & $1.12^{\mathrm{ab}}$ & $6.95^{\mathrm{e}}$ & $0.54^{\mathrm{abc}}$ & $264.93^{\mathrm{e}}$ & $15.22^{\mathrm{c}}$ & $3.01^{\mathrm{bc}}$ & $1.09^{\mathrm{bc}}$ & $1.43^{\mathrm{ab}}$ \\
\hline TSs-87_Cd & $0.02^{\mathrm{a}}$ & $0.66^{\mathrm{a}}$ & $2.47^{\mathrm{b}}$ & $0.46^{\mathrm{a}}$ & $128.04^{\mathrm{a}}$ & $10.06^{\mathrm{a}}$ & $1.37^{\mathrm{a}}$ & $0.26^{\mathrm{a}}$ & $2.30^{\mathrm{cd}}$ \\
\hline TSs-89_U & $0.02^{\mathrm{a}}$ & $4.10^{\text {ghi }}$ & $40.16^{1}$ & $1.64^{\mathrm{f}}$ & $534.30^{\mathrm{k}}$ & $19.66^{\mathrm{f}}$ & $11.21^{\mathrm{i}}$ & $2.48^{\mathrm{de}}$ & $3.92^{\text {ghi }}$ \\
\hline TSs-89_Cd & $0.03^{\mathrm{a}}$ & $2.99^{\mathrm{ef}}$ & $14.65^{\mathrm{g}}$ & $1.33^{\mathrm{ef}}$ & $420.38^{j}$ & $18.07^{\mathrm{e}}$ & $6.14^{g}$ & $1.34^{\mathrm{c}}$ & $5.10^{j}$ \\
\hline TSs-90_U & $0.02^{\mathrm{a}}$ & $2.13^{\text {cd }}$ & $21.21^{\mathrm{i}}$ & $0.84^{\mathrm{abcd}}$ & $224.72^{c}$ & $30.25^{j}$ & $6.41^{\mathrm{g}}$ & $2.01^{\mathrm{d}}$ & $2.01^{\mathrm{bc}}$ \\
\hline TSs-90_Cd & $0.07^{\mathrm{cd}}$ & $1.62^{\mathrm{bc}}$ & $4.42^{\mathrm{cd}}$ & $0.72^{\mathrm{abcd}}$ & $247.95^{\mathrm{d}}$ & $22.63^{\mathrm{gh}}$ & $4.11^{\mathrm{de}}$ & $1.07^{\mathrm{bc}}$ & $2.86^{\mathrm{def}}$ \\
\hline TSs-91_U & $0.02^{\mathrm{a}}$ & $2.03^{c}$ & $6.66^{\mathrm{e}}$ & $0.83^{\mathrm{abcd}}$ & $123.34^{\mathrm{a}}$ & $15.83^{c}$ & $3.01^{b c}$ & $1.09^{b c}$ & $1.79^{b c}$ \\
\hline TSs-91_Cd & $0.04^{\mathrm{b}}$ & $0.70^{\mathrm{a}}$ & $1.51^{\mathrm{a}}$ & $0.48^{\mathrm{ab}}$ & $109.98^{q}$ & $10.00^{\mathrm{a}}$ & $1.07^{\mathrm{a}}$ & $0.25^{\mathrm{a}}$ & $3.55^{\text {fgh }}$ \\
\hline TSs-92_U & $0.02^{\mathrm{a}}$ & $4.45^{\mathrm{i}}$ & $39.03^{\mathrm{k}}$ & $1.61^{\mathrm{f}}$ & $762.78^{n}$ & $18.67^{\mathrm{e}}$ & $11.04^{\mathrm{i}}$ & $2.10^{\mathrm{d}}$ & $3.28^{\mathrm{fg}}$ \\
\hline TSs-92_Cd & $0.03^{\mathrm{a}}$ & $3.03^{\text {ef }}$ & $15.16^{\mathrm{g}}$ & $2.46^{\mathrm{g}}$ & $573.10^{1}$ & $18.06^{\mathrm{e}}$ & $6.55^{\mathrm{g}}$ & $1.40^{c}$ & $4.50^{\mathrm{ij}}$ \\
\hline TSs-93_U & $0.02^{\mathrm{a}}$ & $2.09^{\text {cd }}$ & $21.20^{\mathrm{i}}$ & $1.01^{\mathrm{de}}$ & $405.44^{\mathrm{h}}$ & $30.59^{j}$ & $6.08^{g}$ & $2.01^{\mathrm{d}}$ & $2.01^{b c}$ \\
\hline TSs-93_Cd & $0.02^{\mathrm{a}}$ & $1.57^{\mathrm{bc}}$ & $9.07^{f}$ & $0.96^{\text {cde }}$ & $300.76^{\mathrm{f}}$ & $23.07^{\mathrm{h}}$ & $4.01^{\mathrm{de}}$ & $0.99^{b c}$ & $3.03^{\text {ef }}$ \\
\hline TSs-94_U & $0.03^{\mathrm{a}}$ & $3.66^{\mathrm{gh}}$ & $7.31^{\mathrm{e}}$ & $0.55^{\mathrm{abc}}$ & $206.04^{\mathrm{b}}$ & $16.85^{\mathrm{d}}$ & $3.46^{\mathrm{cd}}$ & $0.95^{b c}$ & $3.31^{\mathrm{fg}}$ \\
\hline TSs-94_Cd & $0.06^{c}$ & $4.02^{\text {ghi }}$ & $2.11^{\mathrm{ab}}$ & $0.42^{\mathrm{a}}$ & $800.71^{\circ}$ & $12.14^{\mathrm{b}}$ & $2.77^{\mathrm{b}}$ & $0.74^{\mathrm{ab}}$ & $8.22^{\mathrm{k}}$ \\
\hline TSs-95_U & $0.03^{\mathrm{a}}$ & $4.13^{\text {hi }}$ & $22.35^{j}$ & $1.16^{\mathrm{de}}$ & $388.22^{\mathrm{g}}$ & $33.08^{\mathrm{k}}$ & $8.80^{\mathrm{h}}$ & $2.63^{\mathrm{ef}}$ & $2.41^{\text {cde }}$ \\
\hline TSs-95_Cd & $0.07^{\mathrm{d}}$ & $2.65^{\mathrm{de}}$ & $4.01^{\mathrm{c}}$ & $0.83^{\mathrm{abcd}}$ & $388.22^{\mathrm{g}}$ & $25.32^{\mathrm{i}}$ & $4.55^{\text {ef }}$ & $2.00^{\mathrm{d}}$ & $1.10^{\mathrm{a}}$ \\
\hline TSs-96_U & $0.03^{\mathrm{a}}$ & $3.01^{\mathrm{ef}}$ & $15.74^{\mathrm{h}}$ & $0.92^{\text {bcde }}$ & $1042.55^{p}$ & $34.21^{1}$ & $6.66^{\mathrm{g}}$ & $2.98^{f}$ & $1.45^{\mathrm{ab}}$ \\
\hline TSs-96_Cd & $0.07^{\mathrm{cd}}$ & $3.50^{\mathrm{fg}}$ & $5.00^{\mathrm{d}}$ & $0.87^{\mathrm{abcd}}$ & $752.81^{\mathrm{m}}$ & $22.27^{\mathrm{g}}$ & $5.00^{\mathrm{f}}$ & $0.96^{\mathrm{bc}}$ & $4.11^{\mathrm{ij}}$ \\
\hline p-value & $1.36 \times 10^{-19}$ & $3.64 \times 10^{-18}$ & $3.27 \times 10^{-50}$ & $3.09 \times 10^{-22}$ & $1.89 \times 10^{-11}$ & $1.73 \times 10^{-41}$ & $2.21 \times 10^{-29}$ & $1.98 \times 10^{-14}$ & $2.95 \times 10^{-21}$ \\
\hline
\end{tabular}

Means with the same alphabetic superscripts on the same column do not differ from each other $(p>0.05) \cdot \mathrm{U}=\mathrm{Unexposed}$, Cd $=\mathrm{Cd}$-exposed. 


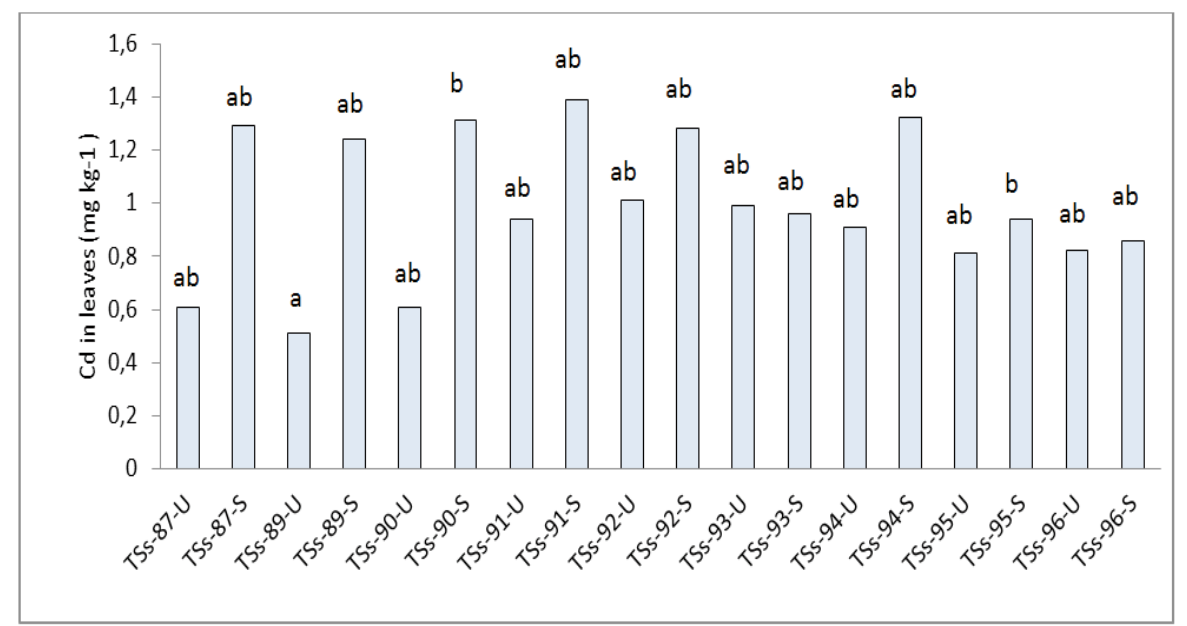

Figure 3: Accumulation of cadmium in leaves of developed emergent of African yam bean at 42 DAS. Bars with the same alphabetic superscripts do not differ from each other $(p>0.05)$. $\mathrm{U}=$ Unexposed, $\mathrm{Cd}=\mathrm{Cd}$-exposed.

bean at 42 DAS. Results showed that certain level of cadmium was detected in leaf of some AYB accessions exposed to cadmium pollution. Metal concentration rose from 0.61 in unexposed TSs-87 to 1.29 in Cdexposed TSs-87. Previous experiments showed that $\mathrm{Cd}$ accumulate rapidly in plants even though it is not required at any concentration by the plants (Vasiliadou \& Dordas, 2009). The present study confirmed that effects of $\mathrm{Cd}$ were measured on growth and development of AYB despite that the plant accumulated small amount in the aerial part. Previous investigation by Ding et al. (2014) showed that Cd accumulated more in aerial parts, thus agreeing with the findings of the present study. This is primarily because of the incorporation of exudates from the root which alters redox states and $\mathrm{pH}$ of the rhizosphere and allow for enhanced Cd mobility (Quezada-Hinojosa et al., 2015). Comparable observation was made for TSs-89 where Cd concentration increased from 0.51 in plant without cadmium pollution to 1.24 in cadmium exposed plant, whereas in TSs-91 metal concentration increased by 0.45 in Cd-exposed plant when compared to the unexposed accession. Observably, there was no significant change in the level of cadmium found in both Cd-exposed and unexposed TSs-93 at 0.96 and 0.99 respectively.

Component plot in rotated space for quantification of oxygen compounds in plant during exposure to cadmium treatment has been presented in Figure 4. Re-

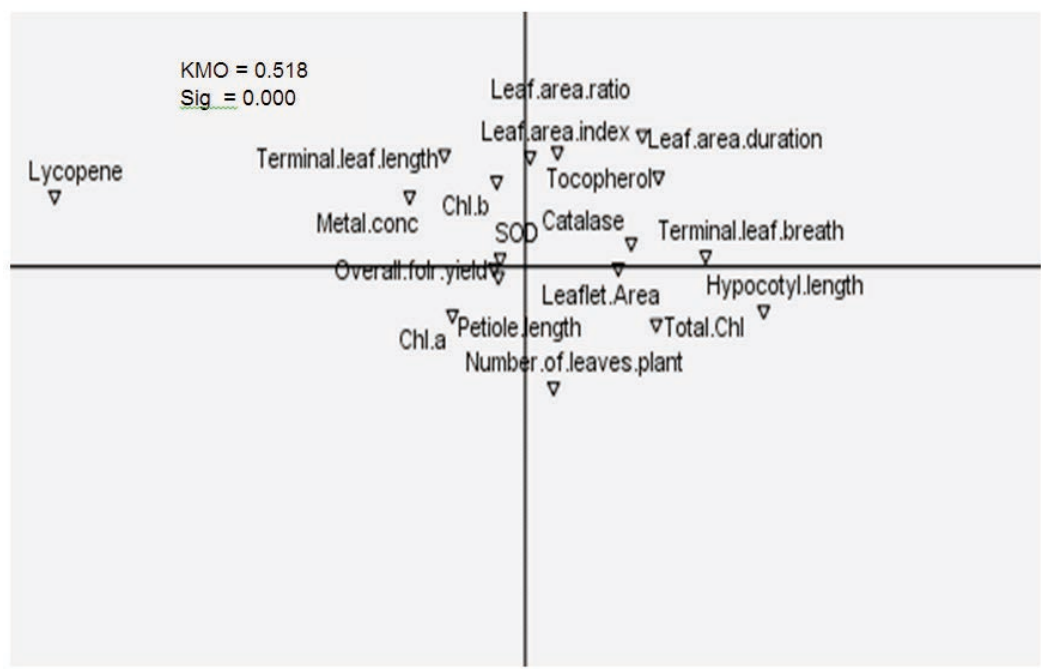

Figure 4: Component plot in rotated space for quantification of oxygen compounds in plant leaves during cadmium exposure 


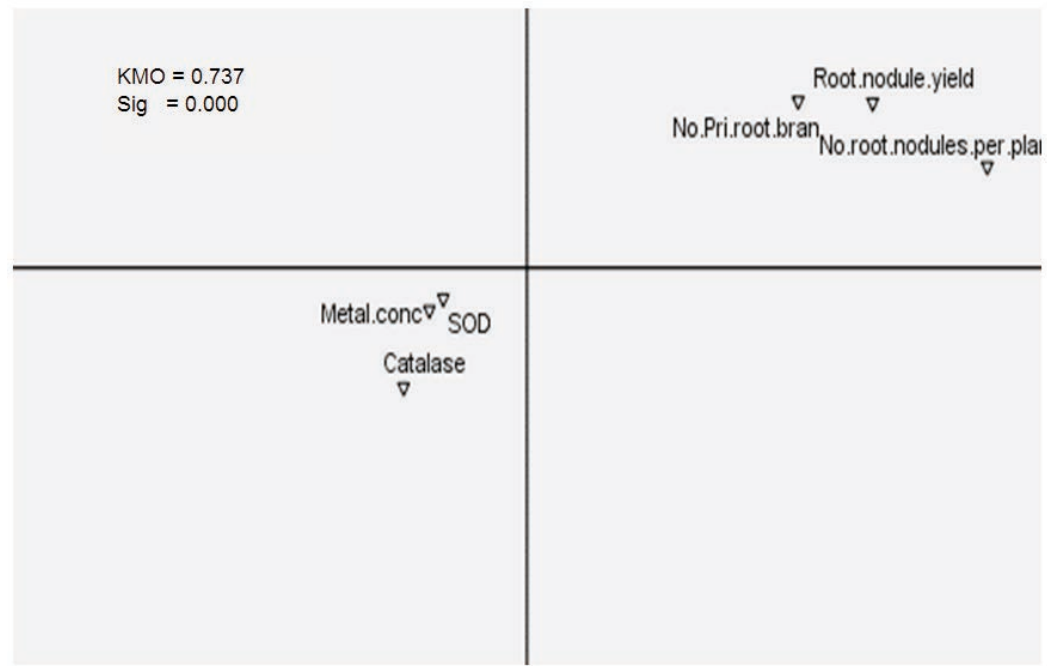

Figure 5: Component plot in rotated space for activity of superoxide dismutase and catalase in African yam bean

sults showed that most parameters including leaf area ratio, terminal leaf length, number of leaves per plant and metal concentration were clustered towards the zero point (point of interception between vertical and horizontal axes). This showed that these parameters contributed less to the variation that involved oxygen compounds in AYB after cadmium treatment. It was observed that lycopene and carotenoids contributed more than superoxide dismutase and catalase in the variation that ensued in AYB after exposure to cadmium contamination. KMO of 0.510 showed that the results of the principal component analysis were reliable.

Concerning the activity of superoxide dismutase (SOD) and catalase in AYB under the influence of cadmium treatment, results showed that parameters such as number of primary branches, root nodule yield, and metal concentration had little control on the activity of the enzymatic antioxidants - SOD and catalase. Figure 5 showed that root length and number of nodules per plant were the key parameters that controlled the activity of SOD and catalase in AYB after exposed to cadmium contamination. $\mathrm{KMO}$ and measure of sampling adequacy showed that the results presented in Figure 7 were reliable in identifying the principal component that had much influence on the variations observed in AYB during the study.

\section{CONCLUSION}

Morphological and physiological responses of nine accessions of African yam bean (Sphenostylis sternocarpa) to $\mathrm{Cd}$ pollution have been investigated. It can be inferred that $\mathrm{Cd}$ engendered different mor- phological and physiological changes in different accessions of African yam bean (AYB). Although incidence of cadmium toxicity negatively affected the period of seedling emergence in contaminated plants, some accessions showed more tolerance capability than others. This work also demonstrated that, in all AYB accessions tested, nitrogen is assimilated more in nitrate form than as ammonium nitrogen. However, cadmium reduced nitrogen assimilation more in the form of nitrate than as ammonium nitrogen. Among all accessions considered in this study, TSs-92 and TSs- 89 were mostly affected by $\mathrm{Cd}$ in terms of yield and tolerance, whereas TSs-93and TSs-90 were the least affected. The question therefore is whether these accessions have any genetic capability to justify these characteristics. This, however, is a study for another time.

\section{ACKNOWLEGEMENT}

The study was funded by the authors. The authors are very grateful to Professor Michael Abberton, Head of Genetic Resources Centre of the International Institute of Tropical Agriculture, Ibadan, Nigeria, for supplying the AYB accessions. The authors also wish to thank Mr. Osazuwa Omoregie and Mrs H. O. Obayuwana for their support during the laboratory sections of the study.

\section{REFERENCES}

Abolghassem, E., Yulong, D., Farzad, M., \& Yinfeng, X. (2015). Heavy metal stress and some mechanisms of plant de- 
fense response. The Scientific World Journal. https://doi org/10.1155/2015/756120

Adewale, D. \& Dumet, D. (2010). African yam bean, a crop with food security potentials for Africa. Journal of African Technological Developmental Forum, 6, 66-71.

Aebi, H. E. (1983). Catalase. In: Methods of enzymatic analysis. Bergmeyer, H.U. (Ed.). Verlag Chemie Weinhem 273 - 286 pp.

Ali, H., Khan, E., \& Sajad, M. A. (2013). Phytoremediation of heavy metals-concepts and applications. Chemosphere, 91(7), 869-881. https://doi.org/10.1016/j.chemosphere.2013.01.075

Anjum, N. A., Umar, S., Ahmad, A., Iqbal, M., \& Khan, N. A. (2008). Ontogenic variation in response of Brassica campestris L. to cadmium toxicity. Journal of Plant Interaction, 35, 189-198. https://doi.org/10.1080/17429140701823164

Anoliefo, G. O., Ikhajiagbe, B., Okoye, P. C., \& Osayi, O. (2016). Utilizing local soap-derived biosurfactant for degradation of petroleum hydrocarbon polluted soils, sustainable remediation in focus. Annals of Science and Techonology, 1(1), 43-51. https://doi.org/10.22366/ast.2016.01.007

Asema, S. U. K., Tanveer, S. T., \& Sultan, S. (2015). Analysis of soil samples for its physico-chemical parameters from Aurangabad City. International Journal of Innovative Research and Development, 4(13), 85-88.

Bashan, Y \& de-Bashan, L. E. (2005). Fresh-weight measurement of roots provide inaccurate estimates of the effects of plant growth-promoting bacteria on root growth: a critical examination. Soil Biology and Biochemistry, 37, 179 -1804. https://doi.org/10.1016/j.soilbio.2005.02.013

Bhattarai, U. \& Subudhi, P. K. (2018). Identification of drought responsive QTLs during vegetative growth stage of rice using a saturated GBS-based SNP linkage map. Euphytica, 214(38), https://doi.org/10.1007/s10681-018-2117-3

Ding, C., Zhang, T., Wang, X., Zhou, F., Yang, Y., \& Yunlong, Y. (2014). Effects of soil type and genotype on cadmium accumulation by rootstalk crops, implications for phytomanagement. International Journal of Phytoremediation, 16, 1018-1030. https://doi.org/10.1080/15226514.2013.81 0581

Dobroviczká, T., Piršelová, B., Mészáros, P., Blehová, A., Libantová, J., Morav- Číková, J. \& Matušíková, I. (2013). Effects of cadmium and arsenic ions on content of photosynthetic pigments in the leaves of Glycine max (L.) Merrill. Pakistan Journal of Botany, 45(1), 105-110.

Efroymson, R. A., Will, M. E., \& Suter, G. W. (1997a). Toxicological benchmarks for screening contaminants of potential concern for effects on terrestrial plants: 1997 revision. ES/ER/TM-85/R3. Oak Ridge National Laboratory, Oak Ridge, TN.

El-Shesheny, M. A., Hendawy, S. H., \& Ahmed, K. M. (2014). Assessment of productivity, botanical composition and nutritive value of some plant communities at Sidi-Barrani in North Western Coast of Egypt. Annals of Agricultural Sciences, 59(2), 155-163. https://doi.org/10.1016/j. aoas.2014.11.001

Eshghi S., Mahmoodabadi, M. R., Abdi, G. R., \& Jamali, B. (2010). Zeolite ameliorates the adverse effect of cadmium contamination on growth and nodulation of soybean plant (Glycine max L.). Journal of Biological and Environmental Science 4, 43-50.

Fukai, H., Tameda, S., Masuda, H., \& Tasaka, M. (2002). Lateral root formation is blockedby a gain-of-function mutationin the solitary-root/IAA14 gene of Arabidopsis. Plant Journal, 29, 153-168. https://doi.org/10.1046/j.09607412.2001.01201.x

Gallego, S. M., Pena, L. B., Barcia, R. A., Azpilicueta, C. E., Iannone, M. F., Rosales, E. P., Zawoznik, S., Gropppa, M. D., \& Benavides, M. P. (2012). Unravelling cadmium toxicity and tolerance in plants, insight into regulatory mechanisms. Environmental and Experimental Botany, 83, 33-46. https://doi.org/10.1016/j.envexpbot.2012.04.006

Ghani, A. (2010). Effect of cadmium toxicity on the growth and yield components of Mungbean [Vigna radiate (L.) Wilczek]. World Applied Sciences Journal, 8, 26-29.

Gill, S. S. \& Tuteja, N. (2011). Reactive oxygen species and antioxidant machinery in abiotic stress tolerance in crop plants. Plant Physiology and Biochemistry, 48, 909-930. https://doi.org/10.1016/j.plaphy.2010.08.016

Gonçalves, J. F., Antes, F. G., Maldaner, J., Pereira, L. B., Tabaldi, L. A., Rauber, R., Rossato, L. V., Bisognin, D. A., Dressler, V. L., Flores, M. E., \& Nicoloso, F. T. (2009). Cadmium and mineral nutrient accumulation in potato plantlets grown under cadmium stress in two different experimental culture conditions. Plant Physiology and Biochemistry, 47, 814-821. https://doi.org/10.1016/j.plaphy.2009.04.002

Gouia, H., Ghorbala, M. H., \& Meyer, C. (2000). Effects of cadmium on activity of nitrate reductase and on other enzymes of the nitrate assimilation pathway in bean. Plant Physiology and Biochemistry, 38, 629-638. https:/doi. org/10.1016/S0981-9428(00)00775-0

Hassanein, R. A., Hashem, H. A., El-Deep, M. H., \& Shouman, A. (2013). Soil contamination with heavy metals and its effect on growth, yield and physiological responses of vegetable crop plants (Turnip and Lettuce). Journal of Stress Physiology and Biochemistry, 9(4), 145-162.

Iranpoura, M., Lakzian, A., \& Zarenia, M. (2016). The effects of cadmium and cow manure on nodulation and growth attributes of common bean (Phaseolus vulgaris L.). International Journal of Environmental and Agricultural Research, 2(10), 69-74.

Kavvadias, V., Paschalidis, C., Vavoulidou, E., Petropoulis, D., \& Koroki, A. (2012). Effects of soil amended with cadmium and lead on growth, yield, and metal accumulation and distribution in parsley. Communications in Soil Science and Plant Analysis, 43(1 - 2), 161-175. https://doi.org /10.1080/00103624.2012.634708

Kumar, A., Dutt, S., Bagler, G., Ahuja, P. S., \& Kumar, S. (2012). Engineering a thermo-stable superoxide dismutase functional at subzero to $>50^{\circ} \mathrm{C}$, which also tolerates autoclaving. Scientific Reports, 387, https://doi.org/10.1038/ srep00387

Mokhele, B., Zhan, X., Yang, G., \& Zhang, X. (2012). Review, Nitrogen assimilation in crop plants and its affecting factors. Canadian Journal of Plant Science, 92, 399-405. https://doi.org/10.4141/cjps2011-135

Munne-Bosch, S. \& Alegre, L. (2002). The function of tocopherols and tocotrienols in plants. Critical Review in 
Plant Science, 21, 31-57. https://doi.org/10.1080/0735260291044179

Munne-Bosch, S. (2005). The role of a-tocopherol in plant stress tolerance. Journal of Plant Physiology, 162, 743-748. https://doi.org/10.1016/j.jplph.2005.04.022

Nada, E., Ferjani, B. A., Ali, R., Bechir, B. R., Imed, M., \& Makki, B. (2007). Cadmium induced growth inhibition and alteration of biochemical parameters in almond seedlings grown in solution culture. Acta Physiologiae Plantarum, 29, 57-62. https://doi.org/10.1007/s11738-006-0009-y

Naz, H., Naz, A., \& Ashraf, S. (2015). Impact of heavy metal toxicity to plant growth and nodulation in chickpea grown under heavy metal stress. International Journal for Research in Emerging Science and Technology, 2(5), 248-260.

Neto, M. C. \& Bartels, P. G. (1992). Dry matter partitioning of cowpea [Vigna unguiculata (L.) Walp.] under water deficit conditions. Vegetable Report, 93, 167-170.

Ohyama, T., Fujikake, H., Yashima, H., Tanabata, S., Ishikawa, S., Sato, T., Nishiwaki, T., Ohtake, N., Sueyoshi, K., \& Ishii, S. (2012). Effect of nitrate onnodulation and nitrogen fixation of soybean. In El-Shemy, H. A., (Ed.) Soybean Physiology and Biochemistry. Intech, Rijeka, Croatia, pp 333-364. https://doi.org/10.5772/17992

Ozalkan, C., Sepetoglu, H. T., Daur, I., \& Sen, O. F. (2010). Relationship between some plant growth parameters and grain yield of chickenpea (Cicer arietinum L.) during different growth stages. Turkish Journal of Field Crops, 15(1), 79-83.

Pál, M., Horvá, E., Janda, T., Páldi, E., \& Szalai, C. (2006). Physiological changes and defense mechanisms induced by cadmium stress in maize. Journal of Plant Nutrition and Soil Science, 169, 239-246. https://doi.org/10.1002/jpln.200520573

Pappalardo, H., Leonardi, C., Genovese, C., Toscano, V., Melilli, M. G., \& Raccuia, S. A. (2016). Effects of heavy metals on seedlings germination and growth in different cardoon genotypes. Acta Horticulturae,1147, 281 - 288. https://doi. org/10.17660/ActaHortic.2016.1147.39

Paschalidis, C., Kavvadias, V., Dimitrakopoulou, S., \& Koriki, A. (2013) Effects of cadmium and lead on growth, yield, and metal accumulation in cabbage. Communications in Soil Science and Plant Analysis, 44(1-4), 632 - 644. https://doi.or g/10.1080/00103624.2013.745373

Paunov, M., Koleva, L., Vassilev, A., Vangronsveld, J., \& Goltsev, V. (2018) .Effects of different metals on photosynthesis, Cadmium and zinc affect chlorophyll fluorescence in durum wheat. International Journal of Molecular Sciences, 19, https://doi.org/10.3390/ijms19030787

Potter, D. (1992). Economic Botany of Sphenostylis (Leguminosae). Economic Botany, 46, 262-275. https://doi.org/10.1007/ BF02866625

Qian, H., Li, J., Sun, L., Chen, W., Sheng, G. D., \& Liu, W. (2009). Combined effects of copper and cadmium on Chlorella vulgaris growth and photosynthesis-related gene transcription. Aquatic Toxicology, 94, 56-61. https://doi.org/10.1016/j. aquatox.2009.05.014

Quezada-Hinojosa R., Föllmi, K. B., Gillet, F., \& Matera, V.(2015). Cadmium accumulation in six common plant species associated with soils containing high geogenic cadmium concentrations at Le Gurnigel, Swiss Jura Mountains. Catena, 124, 85 - 89 https://doi.org/10.1016/j.catena.2014.09.007
Ramel, F., Birtric, S., Soubigou-Taconnat, L., Triantaphylides, C., \& Havaux, M. (2012b). Carotenoids oxidation products are stress signals that mediate gene responses to singlet oxygen in plants. Proceedings of the National Academy of Sciences of the United States of America, 109, 5535-5540. https://doi. org/10.1073/pnas.1115982109

Rascio, N. \& Navari-Izzo, F. (2011). Heavy metal hyperaccumulating plants, how and why do they do it? And what makes them so interesting? Plant Science, 180(2), 169-181. https:// doi.org/10.1016/j.plantsci.2010.08.016

Raveh, A. \& Avnimelech, Y. (1979). Total nitrogen in water, soil and plant material with persulphate oxidation. Water Research, 13(9), 911-912. https://doi.org/10.1016/00431354(79)90227-6

Raveneau, M. P., Coste, F., Moreau-Valancogne, P., LejeuneHe'naut I., \& Durr, C. (2011). Pea and bean germination and seedling responses to temperature and water potential. Seed Science Research https://doi.org/10.1017/ S0960258511000067

Rout, G. R., Samantaray, S., \& Das, P. (1999). Differential cadmium tolerance of Mungbean and rice genotypes in hydroponic cultures. Acta Agriculturae Scandinavica, 49, 234-241. https://doi.org/10.1080/090647100750001604

Sarvajeet, S. G., Mirza, H., Kamrun, N., Anca, M., \& Tuteja, N. (2013). Importance of nitric oxide in cadmium stress tolerance in crop plants. Plant Physiology and Biochemistry, 63, 254-261. https://doi.org/10.1016/j.plaphy.2012.12.001

Singh, S. \& Aggarwal, P. K. (2006). Effect of heavy metals on biomass and yield of different crop species. Indian Journal of Agricultural Science, 76, 688-691.

Skrzyska-Polit, E., Dr_kiewicz, M., \& Krupa, Z. (2010). Lipid peroxidation and antioxidative response in Arabidopsis thaliana exposed to cadmium and copper. Acta Physiologiae Plantarum, 32, 169-175. https://doi.org/10.1007/s11738009-0393-1

Thakur, A. K. \& Singh, K. J. (2014). Seed emergence is more appropriate criterion for testing cadmium toxicity in soybean. International Journal of Food, Agriculture and Veterinary Sciences, 4(2), 129-134.

Vasiliadou, S. \& Dordas, C. (2009). Increased concentration of soil cadmium affects plant growth, dry matter accumulation, $\mathrm{Cd}$, and $\mathrm{Zn}$ uptake of different tobacco cultivars (Nicotiana tabacum L.). International Journal of Phytoremediation, 11(2), 115-130. https://doi.org/10.1080/15226510802378400

Yang, H. Y., Shi, G. X, Xu, Q. S., \& Wang, H. X. (2011). Cadmium effects on mineral nutrition and stress-related induces in Potamogeton criprus. Russian Journal of Plant Physiology, 58, 253-260. https://doi.org/10.1134/ S1021443711020245

Zhang, F., Wan, X. \& Zhong, Y. (2014). Nitrogen as an important detoxification factor to cadmium stress in poplar plants. Journal of Plant Interactions, 9(1), 249-258. https://doi.org /10.1080/17429145.2013.819944

Zong, L. G., Sun, J. K., Shen, Q. Y., \& Zhang, X. P. (2007). Impacts of cadmium and lead pollution in soil on shoot vegetables growth and toxic-symptoms. Asian Journal of Ecotoxicology, 2(1), 63-68. 